VOX PATRUM 21 (2001) t. 40-41

\title{
PATRYSTYKA W CZASOPISMACH 2001 ROKU
}

1. ACTA ANTIQUA 41 (2001) nr 1-4:

M. Pesthy - Das Perlenlied, Origenes und Plotinos 35-40; Z. Kádár Angelus Bonus 105-108; D. Beecher Evans - The Christology of PseudoDionysios the Areopagite 147-156; T. Adamik - Theodulfs Palmsonntagshymnus 165-174; Z. Farkas - $\pi$ or $\Pi$ ? A Note on the Chronology of Eusebius's Martyrs of Palestine 249-254; E. Pataki - „Fiscellas iunco texens". Some Classical Allusions in Jerome's "Vita Hilarionis», Ch 5., 349358

2. ACTA UNIVERSITATIS WRATISLAVIENSIS. HISTORIA (2001) nr 153:

L.A. Tyszkiewicz - Origo gentis Hunnorum 81-90; A. Paroń - Zagadnienie „origines gentium” w dworskiej historiografii bizantyjskiej. Głos w dyskusji 91-95; M. Pandura - Origo Gepidarum 96-102.

3. ADAMANTIUS 6 (2000):

F. Niculescu - Origen in Gethsemane: A View on Origen's Understanding of His Ever-Candidacy to Martyrdom 8-25; M.C. Pennacchio - „Mysteria sunt cuncta quae scripta sunt”: Una ricostruzione dell'esegesi origeniana di Osea 26-50; R. Somos - Origen and Numenius 51-69; R.L. Wilkem - Cyril of Alexandria: Apologist, Biblical Interpreter, Theologian 70-84.

4. ADAMANTIUS 7 (2001):

M. Rizzi- „Non loco sed animo, non timere... sed fide”: l'esegesi origeniana all'Esodo (Hom. Ex. I), 8-24; Ch. Kannengiesser - Prolegomena to the Biography of Athanasius 25-43; R.A. Layton - Didymus and Evagrius on Ps. 118: Bible Study in Fourth-Century Origenism 44-53; I. Perczel „Théologiens” et „magiciens” dans le Corpus Dionysien 54-75; Ph. Blaudeau - Mémoire monophysite et besoins chalcédoniens. Quelques réflexions sur les vestiges de l'"Histoire ecclésiastique» de Jean Diacrinoménos 76-97.

5. AEVUM 75 (2001) nr l-3:

A. Magdeara - A note on the Christians' presence in the "sacer comitatus" before 313 A.D., 111-116; R. Bellini-Inforno all'ebbrezza: sant'Ambrogio e 
la cultura pagana 163-177; S. Serventi - Il Vat. gr. 167, testimone della "Continuatio Theophanis", e $i$,marginalia” di un anonimo lettore byzantino 267-302.

6. ALPHA OMEGA 4 (2001) nr 1:

R. Pascual - Boecio y la division de las ciencias especulativas en el «De Trinitate» 67-86.

7. THE AMERICAN BENEDICTINE REVIEW 52 (2001) nr 1-4:

A. de Vogüé - A Contemporary of Saint Benedict Looks at Monks: The Witness of Procopius 84-103; A. Böckmann - The Sick Monks (RB 36): (I) 171-190, (II) 300-323; K.C. Russel - Cassian's Married Monks 286-299; M. Forman - Benedict's Use of Scripture in the Rule Introductory Understandings 324-345; T. Vivian - „Christ in the Desert” - A Response 393-420; S.M. Hildebrand - „Oboedientia” and „oboedire” in the Rule of St. Benedict. A Study of Their Theological and Monastic Meanings 421-436.

6. ANALECTA BOLLANDIANA 119 (2001) nr 1-2:

Ph. George - Vies et Miracles de saint Domitien, évêque de Tongres-Maastricht (ca. 535-549), (II) 5-32; P. Van Deun - La parenté de la Vierge et du Christ dans une exégèse byzantine de Matthieu 1, 15-16, 33-39; Ch. Walter An Icon of Saint Zosimos of Sozopol 40-44; X. Lequeux - Saint Nicolas d'Andrinople. $\dot{A}$ propos d'une inscription de Thrace Orientale 45-47; G. Colin - L'édition indigène du synaxaire éthiopien 48-58; E. Lucchesi Un nouveau complement aux "Lettres festales" d'Athanase 255-260; D. Afinogenor - The Church Slavonic Life of St. Thaddaios the Martyr of the Second Iconoclasm 313-338.

7. ANAMNESIS 7 (2001) nr 24-25:

G. Jaśkiewicz - Keryks w klasycznej literaturze przedchrześcijańskiej i patrystycznej 21-29; F. Drączkowski - Informacja w stużbie kerygmatu 30-42.

8. ANGELICUM 78 (2001) nr 1-4:

A. Miranda - La risurrezione dei corpi nel Crisostomo (In 1 Cor 15), 387404.

9. ANNALES THEOLOGICI 15 (2001) nr 1-2:

P.G. Alves de Sousa - A penitência no "Pastor» de Hermas mensagem de esperança 551-566.

10. ANNALI DI STORIA DELL'ESEGESI 17 (2000) $\mathrm{nr} 2$ :

M. Pesce - I Giudei, i Romani e la tolleranza religiosa. La rappresentazione di Flavio Giuseppe 355-382; R. Mazza - Documenti dall'Egitto relativi agli ebrei (sec. V-VII) 383-399; T. Nicklas - T.J. Kraus - John 5, 3b-4. Ein längst erledigtes textkritisches Problem? 537-556; S. Taranto - Tra filosofia e fede: una proposta per una ermeneutica dell'escatologia di Gregorio Nisseno 557582; M. Grazia - "La Regula» di Columba. Pro-memoria per eremiti o statuto comunitario? 583-623.

11. ANNALI DI STORIA DELL'ESEGESI 18 (2001) nr 1-2: 
F. Calabi - I sacrifici e la loro funzione conoscitiva in Filone di Alessandria 101-127; A. D'Anna - Sacrificio e Scrittura nell' 'Epistola di Barnaba»181195; M. Rizzi - Il sacrificio pagano nella polemica dell'apologetica cristiana del II secolo 197-209; G. Filoramo - Il sacrificio nei testi gnostici 211-223; E. Zocca - Sacrificio e martirio nella letteratura agiografica del II e III secolo 281-306; F. Ruggiero - La testimonianza di Tertuliano, "Apologeticum»9, 2-4 sul sacrificio dei bambini nell'ambito del culto di Saturno 307-333; G. Folliet - „Iam filli Dei erant in memoriali Patris sui conscripti” («De correptione et gratia» IX 20, 11), 335-344; F. Trisoglio - S. Ambrogio e l'esegesi di S. Massimo di Torino 615-635.

12. ANNUARIUM HISTORIAE CONCILIORUM 32 (2000) $\mathrm{nr} 2$ :

S. Heid - Eine anonyme Kreuzpredigt (BHGa 422w) und das Problem synodaler Festbegründung, 241-263; M. van Esbroeck - Zwei armenische Listen mit Konzilien bis zum Jahre 726, 264-302; R. Haas - Hubert Jedin (1900-1980) und die Kirchen- und Konziliengeschichte des 20. Jahrhunderts 416-429.

13. ANTIKE WELT 32 (2001) nr 1-6:

Ch. Stiegemann - Byzanz. Das Licht aus den Osten. Kult und Alltag im Byzantinischen Reich vom 4. bis 15 Jahrhundert 621-626.

14. ANTIQUITAS 25 (2001):

A. Wypustek - Accusations portées contre les chrétiens aux $I I^{e}$ et $I I I^{e}$ siècles pour détention de livres de magie. Quelques remarques dans la lignée du livre de W. Speyer 179-190.

15. ANTONIANUM 76 (2001) nr 1-4:

H.J. Klauck - Gemeinde und Gesellschaft im frühen Christentum 225-246; B. Huculak - De notionali cardine trinitariae theologiae Graecae 271-294; B. Huculak - De maturo Augustiniano opere Joannis Duns Scoti 429-478; Cz. Teklak - La dottrina ,extra ecclesiam nulla salus” e il suo significato per il dialogo interreligioso 613-649.

16. ANUARIO DE HISTORIA DE LA IGLESIA 9 (2000):

R. Trevijano Etcheverría - La diffusión de la Iglesia en el área mediterránea hasta la paz constantiniana 31-46; D. Ramos-Lissón - El processo evangelizador del norte de África desde la época constantiniana hasta la invasión islámica 47-67; J. Orlandis - La doble conversión religiosa de los pueblos germánicos (siglos IV al VIII), 69-84; V. Peri - La cristianizzazione delle etnie slave (secoli VII-XI), 85-108.

17. ARCHIV FÜR LITURGIEWISSENSCHAFT 42 (2000) nr 1-3:

$\mathrm{H}$. Förster - Die beiden angeblich „ältesten Zeugen” des Weihnachtsfestes 29-40; B. Outtier - S. Verhelst - La „Kéryxie catholique” de la liturgie de Jérusalen en géorgien (Sin. 12 et 54), 41-64; A. Chavasse - Trois notes concernant la liturgie Romaine 344-346.

18. ARCHIV FÜR RELIGIONSGESCHICHTE 3 (2001): 
J. Assman - Das Geheimnis der Wahrheit. Das Konzept der „doppelten Religion" und die Erfindung der Religionsgeschichte 108-134.

19. ARCHIV FÜR RELIGIONSPSYCHOLOGIE 23 (2000):

R. Gothóni - The Healing Quality of Pilgrimage to Mount Athos 132-143.

20. ARCHIVES DE PHILOSOPHIE 64 (2001) nr 1-4:

J.L. Chrétien - Plotin en mouvement 243-258.

21. ART HISTORY 24 (2001) nr 1-5:

K. Bowes - Ivory Lists: Consular diptychs, Christian appropriation and polemics of time in Late Antiquity 338-357.

22. ARTIUM QUAESTIONES 12 (2001):

S. Czekalski - Kallimach i Ojcowie Kościoła. Przyczynek do badań nad geneza artystyczną epitafium Filipa Buonaccorsi 5-24; M. Smolińska-Byczuk - „Papiez Leon I przed Atylla, wodzem Hunów” Józefa Mehoffera 127-159.

23. ATENE E ROMA 46 (2001) nr 1-3:

R. Uglione - Poeti latini in Tertulliano: intertestualità e riscrittura 9-34.

24. ATENEUM KAPŁAŃSKIE (2001) t. 136-137, z. 551-556:

(Z. 555-556) T. Kaczmarek - Tematyka cierpienia w nauczaniu Ojców Kościoła 227-247.

25. ATHENAEUM 89 (2001) nr 1-2:

E.I. Argov - Giving the heretic a voice: Philostorgius of Borissus and greek ecclesiastical historiography 497-524.

26. AUGUSTINIANA 51 (2001) nr 1-4:

(Nr 1-2) J. Lössl - Julian of Aeclanum's «Tractatus in Osee, Iohel, Amos» 11-37; P. Yates - Was there „Augustinian” Concupiscence in pre-Augustinian North Africa? 39-56; G. Folliet - Leçons Nouvelles pour le "De correptione et gratia” 57-63; Ch. Schäfer - „Aqua haeret”. A View on Augustine's technique of biographical self-observation in "De Ordine» 6575; F.B.A. Asiedu - Memory, Truth and Representation at Augustine's Conversion Scene: A Review 77-104; B. Bruning - „Otium” and „Negotium" within the one Church 105-149; P. Paciorek - Les diverses Interprétations patristiques des quatre vivants d'Ezéchiel 1, 10 et de l'Apocalypse 4, 6-7 jusqu'au XII ième siècle 151-218; D.J. Viera - Parallels in fifteenth-century hagiography: John Capgrave's life of St. Katherine of Alexandria and Vincent Ferrer's Catalan sermon on Santa Caterina 231-241; (Nr 3-4) Bibliographie Historique de l'Ordre de Saint Augustin 1996-2000 par A. de Meijer (Histoire générale, locale, personnelle, augustines hagiographie - iconographie) 6-257.

27. AUGUSTINIANUM 41 (2001) nr 1-2:

P. de Navascues - La cristologia pneumàtica en el «De montibus Sina et Sion» 5-25; A. Grappone - Annotazioni sulla cronologia delle omelie di Origene 27-58; M.S. Troiano - II «Contra Eunomium» III di Basilio di 
Cesarea e le «Epistolae ad Serapionem» I-IV di Atanasio di Alessandria nota comparativa 59-91; M. Simonetti - L'edizione critica delle "Enarrationes in Psalmos graduum" (119-133) di Agostino, a cura di F. Gori 93-98; F. Cori - L'edizione critica delle "Enarrationes in Psalmos graduum»: questioni specifiche 99-112; M. Caltabiano - I latori della corrispondenza di Agostino: tra idealizzazione e realtà 113-148; G. Folliet - „Tolerabilior damnatio" - La thèse augustinienne de la mitigation des peines de l'enfer et ses sources scripturaires 149-167; E. Lamirande - „Fidelis” et l'ecclesiologie de S. Augustin. Un thème étrangement négligé 169-200; A. Genovese - Note sull'uso del Cantico dei Cantici in Sant'Agostino 201-212; D. Fiocco L'immagine del vescovo nelle "Vitae Sanctorum" di Venanzio Fortunato 213-230; V. Grossi - Il "Decretum Gelasianum». Nota in margine all'autorità della chiesa di Roma alla fine del sec. V 231-255; G.D. Dunn Suffering Humanity and Divine Impassibility: the Christology in the Lenten Homilies of Leo the Great 257-271; J. Bernardi - Les successeurs immediats de saint Pierre a Rome s'appelaient-ils Clet et Anaclet? 287-290; P. Mattei Angelus ad imaginem? L'anthropologie de Tertulien: vue d'ensemble et nouveaux apercus par le biais de son angélologie (avec une note conjointe sur Novatien) 291-327; A. Grappone - Annotazioni sul contesto liturgico delle omelie di Origene 329-362; C. Noce - La simbologia della veste nel linguaggio cristologico origeniano 363-392; N. Baglivi - Costantino ,segno di contraddizione": il tempo e le maschere di Costantino 393-407; A. Fitzgerald - Christ, Peter and the rooster 409-423; P. Hamblenne - Apponius: le moment, une patrie 425-464; R.C. Hill - „Sartor resartus”: Theodore under review by Theodoret 465-476; $\mathrm{N}$. Cipriani - Rivelazione cristiana e verità in s. Agostino. A proposito di un recente saggio 471-508; A. Genovese Evoluzione e precisazione nell'uso agostiniano del "Cantico de cantici" 509-516; D.V. Proverbio - Un frammento copto dell'omelia cattedrale L di Severo di Antiochie ("In Leontium» II), 517-520; P. Buzi - The Life of Maximus and Domitius: the Cultural Life of the Wadi Al-Natrun in the X Century 521-544.

28. AUGUSTINUS 46 (2001) nr 180-183:

J. Anoz - Dos sermones inéditos de san Agustín de Hipona 5-27; N. Bernex - Ser mujer al amanecer del tercer milenio y a luz de san Agustín 29-44; S. Făgărășanu-Mc Donnel - San Agustín y la cuestión del origen de las palabras 45-53; C.D. Lasa - Interioridad y palabra en san Agustín de Hipona 55-83; C.J. Neumann Paulo - Agustín, la fenomenología y el existencialismo 85-129; P. Rigby - „Se reirá de mí”. Tributo posmoderno a la ética de Agustín 131-146; J. Wetzel - El teatro de la memoria. Una mirada a las certezas posmodernas de Agustín 147-155; C.J.N. De Paulo - Fenomenología agustiniana de la inquietud humana 199-224; J.A. Galindo Rodrigo - El acuerdo de la Iglesia Católica y la Federación Luterana Mundial sobre la 
justificación, y su convergencia con la doctrina de san Agustín 225-250; E. LaRock - Tiempo, mente e identidad personal, según Agustín 251-270; F. Navarro Coma - „Epistulam asiarchae misimus”. Una misteriosa carta perdida de Agustín 271-289; E. Sánchez - El comentario de Ambrosio y Agustín sobre la perícopa de la adúltera (Jn 7, 53-8, 11), 291-344; F. Van Fleteren - Algunos principios olvidados de hermenéutica agustiniana 345359.

29. THE BIBLE TODAY 39 (2001) nr 1-6:

E.G. Mathews - The Latin Versions of the Bible 39-42.

30. BIBLIOTHECA SACRA 158 (2001) nr 629-632:

J. Bingham - The Practice of Prayer in Early and Medieval Monasticism 104-115.

31. BIBLISCHE NOTIZEN (2001) nr 106-109:

(Nr 106) E. Verhoef - Pseudoepigraphy and Canon 90-98.

32. БЪЛГАРРСКО БОГОСЛОВИЕ 3 (2001):

П. Стефанов - Етика на гностическата религия 62-67.

33. BOGOSLOVNI VESTNIK 61 (2001) nr 1-4:

A. Arko-Razsežnost zemlje v «Življenju sv. Makrine»sv. Gregorja iz Nise 47-62.

34. BULLETIN DE L'ASSOCIATION GUILLAUME BUDÉ (2001) nr 1-3: M. Perrin - Regards croisés sur la couleur, de l'Antiquité au Moyen Âge autour quelques notes de lecture 153-170; É. Wolff - Les jeux de langage dans l'Antiquité romaine 317-334; C. Lévy - Rhétorique et éthique. A propos d'un ouvrage recent 335-351.

35. BULLETIN DE LITTERATURE ECCLÉSIASTIQUE 102 (2001) nr 1-4: $\mathrm{Ph}$. Foro - La mémoire des catacombes de Rome 25-38; Ph. Molac - L'image de Julien l'A postat chez saint Grégoire de Nazianze 39-48; J. Rigal - Unité et diversité dans l'Église 195-216; S.T. Bonino - Philosopher face aux Barbares: Boèce et Cassiodore 295-308.

36. THE BULLETIN OF THE AMERICAN SOCIETY OF PAPYROLOGISTS 37 (2000) nr 1-4:

Ph. Sellew - An Early Coptic Witness to the «Dormitio Mariae» at Yale: P.CtYBR inv. 1788 Revisited 37-69; D. Brakke - The Body as Eastern Christian Sources 119-134; J.K. McVay - The Human Body as Social and Political Metaphor in Stoic Literature and Early Christian Writers 135-147.

37. BYZANTINISCHE ZEITSCHRIFT 94 (2001) nr 1-2:

M. De Groote - Opera (Pseudo-) Oecumeniana. Das sonstige, echte und vermeinte Oeuvre des Apokalypse-Exegeten Oecumenius 20-28; O. Schmitt - Oströmische Herrschaft in Vorderen Orient (628 und 633), 197-229; K.I. Todt - Das Patriarchat von Antiocheia in mittelbyzantinischen Zeit (9691084), 239-267; N.G. Wilson - The Peckover Codex of Theodore Studites 268-271; A. Alexakis - The Epistula ad Marinum Cypri presbyterum (CPG 
7697. 10) Revisited: A Few Remarks on Its Meaning and Its History 545-554; C. Bevegni - Un recente saggio sul Fortleben della «Bibliotheca» di Fozio 555-563; H.A. Klein - Niketas und das wahre Kreuz. Kritische Anmerkungen zur Überlieferung des Chronicon Paschale ad annum 614, 580-587; D.R. Reinsch - Textkritisches zu den Büchern 1-14 der Alexias Anna Komnenes 608-640.

38. BYZANTION 71 (2001) nr 1-2:

A. Babuin - Standards and Insignia of Byzantium 5-59; C. Macé - Les Histoires mythologiques du Pseudo-Nonnos et la tradition des Discours de Grégoire de Nazianze. A propos du manuscript Sélestat, Bibliothèque municipale, 105, 110-130; G.C. Maniatis - Operationalization of the Concept of Just Price in the Byzantine Legal, Economic and Political System 131-193; A. Messina - Il codice Vat. Gr. 1591 ed il romanzo agiografico siciliano 194211; Th. Brauch - Patristic and Byzantine Witness to an Urban Prefectship of Themistius under Valens 325-282; A. Knaepen - L'image du roi vandale Gélimer chez Procope de Césarée 383-403; Ch. Lacombrade - Hypatic, Synésios de Cyrène et le patriarcat alexandrin 404-421; J. Mossay - Nazianze, Nenezi. Bekârlar 438-450; V. Somers - Description des collections complètes des "Orationes» de Grégoire de Nazianze: Quelques compléments 462-504.

39. LES CAHIERS DE LA FACULTÉ DE THÉOLOGIE (2001) nr 8:

A. Louf - Quelques constantes du parcours spirituel d'un chrétien 9-34; J. Aubin - Communion à Dieu et aux frèrer dans l'expérience bénédictine 75-89.

40. CAHIERS DU CERCLE ERNEST RENAN (2001) nr 213-216:

( Nr 213) B. Alexandre - L'Église primitive et le service militaire 5-32; A. Lama - La chute de Rome a-t-elle en aussi des causes ethniques (suite) 63-111; (Nr 214) Gys-Devic - Celse, polémiste antichrétien 11-120; ( Nr 215) L. Blaise - Conjounctures sur le Christianisme 35-56; (Nr 216) P. Dane L'Evangile de Jésus selon saint Coran 5-14; A. Lama - Les Flaviens et le judaïme 15-54.

41. CATÉCHESE REVUE DE PASTORALE ET DE FORMATION (2001) nr 162-165:

(Nr 163) J.L. Pouthier - Ph. Boutry - Aux sources du pèlegrinage chrétien 15-22.

42. CATHOLICA (2001) nr 1-4:

J. Freitag - Katholizität als Lernprinzip 157-176; G. Gäde - „Extra Ecclesiam nulla salus"? Ein patristisches Axiom und der heutige religiöse Pluralismus 194-214.

43. CENOBIUM (2000) nr 15-16:

(Nr 15) A. Jankowski - Reguła św. Benedykta rozdział 68, 40-47; Św. Bernard z Clairvaux - Kazanie drugie o Pieśni nad pieśniami, thum. A. 
Haberko 48-57; Hildegarda z Bingen - Scivias. Pierwsza wizja z trzeciej części dzieła, tłum. A. Haberko 58-60; (Nr 16) A. Jankowski - Duch Święty $w$ regule benedyktyńskiej 7-19.

44. DER CHRISTLICHE OSTEN 56 (2001) nr 1-6:

G. Adler - „Du sollst dir kein Gottesbildnis machen”. Zur Geschichte des Bilderverbots 84-99; O.F.A. Meinardus - Die Kopten: Miaphysiten statt Monophysiten 112-118; P. Plank - Trier als gemeinsamer Wallfahrtsort für orthodoxe und katholische Christen 119-132; D.W. Winkler - Sprache und Literatur der syrischen Tradition 136-145; V.R. Jeck - Platonismen in der Ikonentheorie des Johannes von Damaskus 209-215; M.H. Duffner - Ein kleines Kind, der urewige Gott 259-276; K. Zelleke - Von Ikonen und Hymnen in Äthiopien 277-284.

45. CHRISTUS 48 (2001) nr 189-192:

A. Louf - Violence chez les moines? 427-436.

46. CHURCH HISTORY 70 (2001) nr 1-4:

D. Brakke - The Making of Monastic Demonology: Three Ascetic Teachers on Withdrawal and Resistance 19-48; D. Boyarin - Justin Martyr Invents Judaism 427-461; G. Frank - ,Taste and See”: The Eucharist and the Eyes of Faith in the Fourth Century 619-643.

47. CHURCHMAN 115 (2001) nr 1-4:

C.A. Blaising - William J. Abraham's Canon and Criterion in Christian Theology: From the Fathers to Feminism 103-109.

48. CIENCIA TOMISTA 92 (2001) t. 128, nr 414-416:

L. Díez Merino - El hombre imagen y semejanza de Dios en la literatura judía antigua 276-315.

49. CISTERCIAN STUDIES QUARTERLY 36 (2001) nr 1-4:

T.G. Kardong - Saint Benedict and the Twelfth-Century Reformation 279309; A. de Vogüé - How Ought Novices To Be Formed in Stability Today, trans. C. Del Cogliano 311-316; Bernard of Clairvaux - A Sermon for the Feast of Saint Benedict, trans. F.R. Swietek - J.R. Sommerfeldt 319-324; D. Bertrand - Bernardine Discernment: Between the Desert Fathers and Ignatius of Loyola, trans. B. Kerns 325-336; P.T. Gray - Blessed is the Monk: Isaac of Stella on the Beatitudes 349-365; E. Scholl - The Mother of Virtues: Discretio 388-401; E. Sellner - Cassian and the Elders: Formation and Spiritual Direction in the Desert and Today 417-435; A. de Vogüé The Search for God in Saint Benedict's Rule, trans. J.B. Hasbrouck 437446; G.K. Anderson - Designed for Prayer: A Bibliographical Essay on Medieval Monasticism for Contemporary Designers and Gardeners 457471.

50. COLLATIONES 31 (2001) nr 1-4:

G. Honnay - Augustinus' kijk op vreugole. Een kennismakiing 183-192.

51. COLLECTANEA CISTERCIENSIA 63 (2001) nr 1-4: 
Colomba Marmion - La vie monastique selon les principes de saint Benôt 234-239; F. Ruppert - Il n'est qu'un représentant. L'image de soi de l'abbé d'après saint Benoît 240-251.

52. COLLECTANEA THEOLOGICA 71 (2001) nr 1-4 + numer specjalny:

(Nr specjalny) K. Bardski - Gen 22, 1-14. Les intuitions parallèles des traditions juive et chrétienne dans le dialogue créatif entre le texte biblique et la communauté de foi 5-13.

53. COMMUNIO (USA) 28 (2001) nr 1-3:

P.S. Russell - Making Sense of Scripture: An Early Attempt by St. Ephraem the Syrian 171-201.

54. COMMUNIO VIATORUM 43 (2001) nr 1-3:

J.B. Pool - „Non intratur in veritatem, nisi per charitatem”: Toward a Christian Hermeneutic of Love 159-188.

55. CONNAISSANCE DES PÈRES DE L'ÉGLISE (2001) nr 81-84:

(Nr 81: L'Arménie) B. Outtier - Les Pères de l'Église en Arménie et les Pères de l'Église 2-4; B. Outtier - Le christianisme en Arménie 5-20; B.L. Zekiyan - Quelques réflexions préliminaires sur l'identité chrétienne de l'Arménie: l'universalité de la Parole et son Incarnation dans la vie de l'ethnos 21-37; V. Calzolari - La Bible et les textes apocryphes dans l'Arménie ancienne 38-51; C. Renoux - La Pâque du dimanche à Jérusalem au IV siècle 52-58; ( $\mathrm{Nr}$ 82: Irénée de Lyon) J. Fantino - Irénée de Lyon (vers 140-200), sa vie et son œuvre 2-10; M. Scopello - Irénée et les gnostiques 11-17; J. Fantino - L'économie, réalisation du dessein de Dieu 18-34; B. Sesboué - Économie du salut et récapitulation dans la théologie d'Irénée de Lyon 36-50; M.L. Chaieb - Anthropologie et action de grâce chez Irénée 51-56; N. Kriegel - La figure d'Abraham chez Irénée de Lyon 57-60; ( Nr 83: Mani et le manichéisme) J.D. Dubois - La redécouverte actuelle du manichéisme 3-15; J. van Oort - Le Codex manichéen de Cologne et son importance 17-24; G. Wurst - Le Psautier manichéen copte de Medinet Mâdi 2534; M. Scopello - Femmes et propagande dans le manichéisme 35-44; J.K. Coyle - Augustin et le manichéisme 45-55; M.N. Vignal - Le personnage de Moïse au Livre VIII du «Contre Julien» de Cyrille d'Alexandrie 5659; ( Nr 84: La création) M.A. Vannier - La création chez les Pères 2-9; J. Fantino - La création d'après S. Irénée 10-22; L. Brottier - La lecture chrysostomienne des deux premiers chapitres de la Genèse: une création ordonnée et offerte en spectacle à l'homme 23-31; M.A. Vannier - La création et son accomplissement chez S. Augustin 32-43; C. Pasquet - La création chez les Pères syriaques 44-55; B. Tataru-Cazaban - Colloque international: Jean Cassien entre Orient et Occident 57-61.

56. CONTACTS 53 (2001) nr 193-196:

E. Theokritoff - Prier les Écritures dans la tradition liturgique orthodoxe 6-30; H. Alfeyev - L'héritage patristique et la modernité 107-143; Hiérodiac- 
re Job (Getcha) - L’homélie de saint Gregoire le Théologien «De l'amur des pauvres» et ses liens avec la question de l'environnement et de la pauvreté 144-151; M. Stavrou - La dimension pneumatique de la christologie des Pères grecs 196-205.

57. CRISTIANESIMO NELLA STORIA 22 (2001) nr 1-2:

V. De Fraja - Percorso storico e significato del monachesimo benedettino nell' "Expositio vitae et regulae Benedicti» di Gioacchino da Fiore 381-435.

58. LA CULTURA 39 (2001) nr 1-3:

G. Arnaldi - Gregorio Magno e la difficoltà inerenti all'esercizio del potere temporale 35-54.

59. CZASOPISMO PRAWNO-HISTORYCZNE 53 (2001) nr 1:

F. Longchamps de Bérier - Niektóre przykłady nadużycia prawa w rzymskim prawie prywatnym: władza ojcowska 159-167.

60. DEUTSCHES ARCHIV FÜR ERFORSCHUNG DES MITTELALTERS 56 (2000) nr 1-2:

K. Zechiel-Eckes - Verecundus oder Pseudoisidor? Zur Genese der Excerptiones de gestis Chalcedonensis concilii 413-446.

61. DEUTSCHES ARCHIV FÜR ERFORSCHUNG DES MITTELALTERS 57 (2001) nr 1:

H. Hoffmann - Autographa des früheren Mittelalters 1-62.

62. DIALOG TEOLOGIC 4 (2001) nr 7:

A. Bulai - Inceputul Bisericii după Faptele Apostolilor 33-46.

63. DIALOGUES D'HISTOIRE ANCIENNE 26 (2000) nr 1-2:

(Nr 1) N. Tlili - Les bibliothèques en Afrique romaine 151-174; S.M. Perevalov - Bazas 414: la rupture de l'alliance alano-gothique 175-193.

64. DIDASKALIA 31 (2001) nr 1-2:

(Nr 1) M.A. Saint-Maurice Esteves - La place de l'homme dans le monde selon Celse et selon Origène 21-40; I. Lamelas - Mistério da Trinidade e Maria em Potâmio de Lisboa (?-c. 360) 61-87; C. Silva - Gnose Benedita - Realização espiritual e suas contrafacçes vecents 88-123; ( $\mathrm{Nr} 2$ ) M. da Graça Pereira Coutinho - A Graça e o Tempo em Santo Agostinho 27-70; I. Lamelas - Sobre a edição de textos patrísticos em língua portuguesa 131-139.

65. DIDASKALOS (2001) nr 4 (Dziecięctwo Boże):

M. Lechniak - Rozwój biologiczno-psychiczny a rozwój duchowy człowie$k a$ (na podstawie rozróżnień św. Augustyna) 34-66; Św. Augustyn $Z$ traktatów na temat Ewangelii św. Jana (traktat XI, PL 35, 1389-1976), tłum. K. Paczos 189-204.

66. DIVUS THOMAS 104 (2001) nr 28-30:

(Nr 28) G. Bendinelli - Origene e il descensus ad infernos 183-210.

67. EARLY MEDIEVAL EUROPE 10 (2001) nr 1-3:

M.A. Handley - The origins of Christian commemoration in late antique Britain 177-199; P. Stafford - Review article: Parents and Children in the 
Early Middle Ages 257-271; D. McCarthy - The chronology and sources of the early Irish annals 323-341.

68. ECCLESIA ORANS 18 (2001) nr 1-3:

M.S. Gros - La vigile pascale à Vérone dans les années 360-380, 11-23; M. Carlin - The Mozarabic Rite of Presbyteral Ordination: A Diachronic Study 25-40; G. Caputa - La mediazione sacerdotale del verbo incarnato secondo Beda il Venerabile 73-103; D.J. Sieverding - The Reconciliation of the Heretically Baptized in the Western Medieval Liturgical Books 173-221; J. Driscoll - Uncovering the Dynamic „Lex orandi - Lex credendi” in the Anaphora of The "Apostolic Tradition» of Hippolytus 327-364; M.S. Gros Gaudence de Brescia témoin de la célebration eucharistique vers l'an 400, 365-371.

69. ELPIS 3 (2001) $\mathrm{nr} 4-5$ :

(Nr 4) H. Paprocki - Anafora saidzka z VII wieku i jej relacja do Anafory św. Bazylego Wielkiego 119-145; (Nr 5) W.A. Tsigkos - Ksztattowanie się terminu „Theotokos” w okresie soborów powszechnych $i$ jego znaczenie chrystologiczno-soteriologiczne 9-32; F. Jeanlin - La Vierge Marie dans l'histoire du salut 33-43 (thum. H. Paprocki: Dziewica Maria $w$ historii zbawienia 44-54).

70. EMERITA 69 (2001) nr 1-2:

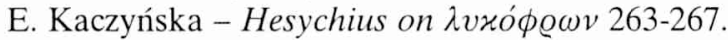

71. EPHEMERIDES LITURGICAE 115 (2001) nr 1-4:

A.G. Kollamparampil - „For us and for our salvation”: A Liturgical Approach to Soteriology in the Syriac East 68-81; S. Parenti - La preghiera di elevazione „Verbo incomprensibile” della Liturgia di S. Giacomo ed il suo impiego nell'eucologio italo-bizantino 193-207; A.M. Tracca - L'Opera della Trinità in Maria secondo la Liturgia ambrosiana 343-374; E. Mazza - La celebrazione della penitenza nella liturgia bizantina e in Occidente: due concezioni a confronto 385-440.

72. EPHEMERIDES MARIOLOGICAE 51 (2001) nr 1-4:

(Nr 1) Índices de Ephemerides Mariologicae 1976-2000.

73. EPHEMERIDES THEOLOGICAE LOVANIENSES 77 (2001) nr 1-4: J.A. Konat - Christological Insights in Jacob of Serugh's Typology as Reflected in his «Memre» 46-72; A. Meis Wörmer - Die Verborgenheit Gottes im Hohenliedkommentar Gregors von Nyssa und ihre Rezeption durch Pseudo-Dionysius Areopagita 73-107; T. Baarda - John 1, 176: The Origin of a Peshitta Reading 153-162.

74. ERBE UND AUFTRAG 77 (2001) nr 1-6:

P. Luislampe - Die Kontemplation als wesentliche Dimension der benediktinischen Spiritualität 5-19; A. Jensen - Frauen in der Asketengeschichte «Das Paradies» von Palladios (Historia Lausiaca) 99-116; J. Werner „Artifices si sunt in monasterio”- Anmerkungen zum 57. Kapitel der Re- 
gula Benedicti 164-168; K. Suso Frank - Asketinnen in den «Apophtegmata Patrum» 211-225; J. Hofmann - Äbtissin Anthousa von Mantineon - geistliche Mutter eines Doppelklosters im Zeitalter des Ikonoklasmus 226-238; P. Bielefeld - Ch. Brüning - Psalm 148 in Gebet der Kirche 273-284; A. Altenähr - Der Oblatenrektor. Regelüberlegungen zu seinem Profil 367-373; T. Heither - Unterwegs zur Freiheit mit den Kirchenvätern 393414; A. Böckmann - Liturgie nach der RB, 478-489.

75. ESPE (2001) nr 54-57:

(Nr 54) Eatwo bowiem mówić: Wierzę w Boga... (fragmenty: Cezary z Arles, Kazanie 20, 3, PSP 52, 98-99), wybrał A. Langhammer 94-96; (Nr 55) Przez wspólnotę sakramentów dobrzy sa pomieszani ze złymi (fragmenty: Ignacy z Antiochii, List do Magnezjan, PSP 45, 73-75; Fulgencjusz z Ruspe, OŻ I 24-25), wybrał A. Langhammer 102-104; (Nr 56) Sami sobie zaptate wyznaczamy (fragmenty: Orygenes, $O$ zasadach 10, 4, PSP 23, 182-183), 94-95; (Nr 57) Pojawiła się święta Maryja... (fragmenty: Cyryllonas, Pieśn o nawróceniu Zacheusza, OŻ III 382-383; modlitwa z liturgii koptyjskiej, OŻ IV 74), 68-69; E. Kryściak - Święta Matka (św. Monika) 69-70.

76. ESTUDIO AGUSTINIANO 36 (2001) nr 1-3:

P. Pe Luis - Estructura de la Regla de san Agustín (XI) 5-29, (XII) 255-280; P. De Luis - Comentario de la Regla de san Agustín. Capítulo segundo (I) 495-532; Th. G. Sinnige - Cristianismos en el idioma filosófico de las «Enéadas» de Plotino 613-617.

77. ESTUDIOS BÍBLICOS 59 (2001) nr 1-4:

A. Moreno García - R. Saez Gonzalvez - El problema de los idolotitos en 1 Co 8-11 como humus de los banquetes judeo-cristianos 47-78; A. Urbán Algunas peculiaridades bíblico-literarias en el anónimo «De ortu et obitu patriarcharum» 501-536.

78. ESTUDIOS TRINITARIOS 35 (2001) NR 1-2:

E. García López - La utopía en S. Agustín, en Erasmo y en Santo Tomás Moro 77-113.

79. ETHOS 14 (2001) nr 53-56:

(Nr 53-54) J. Śrutwa - Myśli o męczennikach z pierwszych wieków Kościoła 91-100; J. Szlaga - Fenomen męczeństwa w Kościele czasów apostolskich 101109; D. Sullivan - Pojęcie męczeństwa we wspótczesnym Kościele irlandzkim, tłum. D. Chabrajska 211-222; (Nr 56) B. Burdziej - ,, Galilaee vicisti”. Postać Juliana Apostaty w literackich sporach o chrześcijaństwo 173-191.

80. LES ÉTUDES CLASSIQUES 69 (2001) nr 1-3:

M. Federspiel - Sur un théorème de Jamblique ( "In Nic.», 52, 28 - 55, 5, P.) et de Boèce ("Instit. Mus.»II, 9) 141-170.

81. ÉTUDES BALKANIQUES (2000) nr 1-4:

(Nr 2) Ts. Cholova - Medieval Science in the Balkans (4th - 15th cc.) 112126; (Nr 3 ) L. Simeonova - Constantinopolitian Attitudes toward Aliens and 
Minorities, 860s-1020s. (I) 91-112; (Nr 4) C. Dimitrova-Choudilova - Unknown Inscription on a Justin I and Justinian I Coin (4 April - 1 August 527), 138-141.

82. THE EXPOSITORY TIMES 113 (2001) nr 1-3:

(Nr 3) J.K. Elliott - Art and the Christian Apocrypha 84-87.

83. FAITH \& REASON 26 (2001) nr 1-4:

J.L.A. West - St. Augustine on Human Temporality and Divine Eternity 143-155.

84. FILOZOFSKI VESTNIK 22 (2001) nr 1-2:

(Nr 1) M. Vesel - Boetij o kompatibilnosti vnaprejšnje božje vednosti in prihodnjih kontingentnih dogodkov 7-31.

85. FRANCIA 27 (2000) nr 1:

G. Kampers - Caretena - Königin und Asketin. Mosaiksteine zum Bild einer burgundischen Herrscherin 1-32; K. Zechiel-Eckes - Zwei Arbeitshandschriften Pseudoisidors (Codd. St. Petersburg F. v. I. 11 und Paris Cat. 11611), 205-210.

86. GREGORIANUM 82 (2001) nr 1-4:

$\mathrm{H}$. Pietras - Le ragioni della convocazione del Concilio Niceno da parte di Costantino il Grande 5-35; N. Tanner - The Eucharist in the Ecumenical Councils 37-49; L.B. Porter - Sheep and Shepherd: An Ancient Image of the Church and a Contemporary Challenge 51-85; T. Śpidlík - Il volto di Cristo nella spiritualità orientale 515-526; G. Strola - I Sal $42-43$ nella storia dell'esegesi 637-688.

87. HAGIOGRAPHICA 7 (2000):

N. Everett - The Hagiography of Lombard Italy 49-126; J.C. Martín - Une nouvelle édition critique de la «Vita Desiderii» de Sisebut, accompagnée de quelques réflexions concernant la date des "Sententiae" et du "De viris illustribus» d'Isidore de Séville 127-180; G.P. Maggioni - La «Vita sanctae Theodorae» (BHL 8070). La revisione imperfetta di una traduzione perfettibile 201-268.

88. HARVARD THEOLOGICAL REVIEW 94 (2001) nr 1-4:

S.P. Bergjan - Celsus the Epicurean? The Interpretation of an Argument in Origen "Contra Celsum»179-204; N. Denzey - What Did the Montanists Read? 427-448; D. Kimber Buell - Rethinking the Relevance of Race for Early Christian Self-Definition 449-476; M.E. Stone - Armenian Canon Lists VI - Hebrew Names and Other Attestations 477-491.

89. HERMENEIA (2001) nr 1-4:

(Nr 1) O.F. Meinardus - Zur koptischen Chronologie und Ikonographie des hl. Josephus 7-19; J. Zerlin - Im Spiegel der Lampen - Von den Anfängen christlicher Symbolik und Ikonographie an spätantiken Öllampen (I) nr 1, 30-37; (II) nr 2, 49-52; (III) nr 3, 53-59; (Nr 2) A. Hart - Heilige des I. Jahrtausends in Britannien und Irland (Schluss) 33-48. 
90. HERMES 129 (2001) nr 1-4:

M.G. Bajoni - La retorica della memoria: A proposito degli epicedi di P. Berol. Inv. 10559/10558 e della „Commemoratorio professorum Burdigalensium” di Ausonio 110-117; Ch. Pietsch - „Aeternas temptare vias”. Zur Romidee im Work des Prudentius 259-275; M. Meier - Der „Kaiser der Luppa". Aspekte der politischen Kommunikation im 6. Jahrhundert $n$. Chr. 410-430; F. Pontani - F. Schironi - Supplementum Hellenisticum (=S.H.) 1025: Definitely Gregory of Nozianz 439-440; M. Hoffmann Statianische Szenen im „Peristephanon” des Prudentius 533-541.

91. HISTORIA 50 (2001) nr 1-4:

N. Dörner - Ambrosius in Trier. $\mathrm{Zu}$ den Hintergründen der zweiten Gesandtschaft bei Maximus (Ambrosius, Epist. 30 [24]), 216-244; S. Benoist Le prince, la citè el les événements: l'année 68-69 à Rome 279-311; A. Berriman - M. Todd - A Very Roman Coup: the Hidden War of Imperial Succession AD 96-98, 312-331; S.S. Miller - Josephus on the Cities of Galilee: Factions, Rivalries and Alliances in the First Jewish Revolt 453-467; S. Dmitriev - The End of provincia Asia 468-489.

92. HISTORY AND COMPUTING 12 (2000) nr 1:

D. Thornton - Computerizing Celtic Kings and clerics: towards a prosopography of early Medieval Ireland 31-41; D. Smythe - Putting technoloy to work: the CD-ROM version of the Prosopography of the Byzantine Empire (641-867), 85-97.

93. INTERNATIONALE KIRCHLICHE ZEITSCHRIFT 91 (2001) nr 1-4: M. Parmentier - Was war die Sünde Sodoms? Eine mittelalterliche Umfrage 274-288.

94. ISIDORIANUM 10 (2001) nr 19-20:

J.A. Antón Pacheco - Algunos aspectos de la hermenéutica en la antigüedad 403-430.

95. ISTINA 46 (2001) nr 1-4:

J. Yacoub - Les versions araméennes de la Bible 116-126; B. Dupuy L'édition de Leyde de la Peshitta de l'Ancien Testament 127-138; J. Dorfmann-Lazarev - „Nature” et „,sujet” après Éphèse: essai sur la complémentarité des langages christologiques 139-154; B. Dupuy - Quel est l'auteur de l'Anaphore de Nestorius? 155-159; Les Symboles de foi de l'Église de l'Orient au quatrième siècle 162-167.

96. JAHRBUCH FÜR BIBLISCHE THEOLOGIE 15 (2001):

E. Dassmann - Menschenrechte und Menschenwürde in frühchristlicher Zeit 151-179.

97. JAHRBUCH FÜR LITURGIK UND HYMNOLOGIE 39 (2000):

H.M. Niemann - Literaturbericht zur Liturgik. Altorientalische und Israelitisch-Jüdische Religion 100-141.

98. THE JEWISH QUARTERLY REVIEW 91 (2000) nr 1-4: 
Y. Maori - Is The Peshitta a Non-Rabbinic Jewish Translation? (Review Essay) 411-418.

99. JOURNAL FOR THE STUDY OF THE NEW TESTAMENT 80 (2000) nr 79-84:

(Nr 79) B. Wehn - „Blessed are the bodies of those who are virgins”: Reflections on the Image of Paul in the "Acts of Thecla" 149-164; (Nr 80) T.B. Sailors - Wedding Textual and Rhetorical Criticism to Understand the Text of 1 Thessalonians 2, 7, 81-98; (Nr 83) Th. E. Phillips - Revisiting Philo: Discussions of Wealth and Poverty in Philo's Ethical Discourse 111-121.

100. JOURNAL OF BELIEFS \& VALUES 22 (2001) nr 1-2:

J. Zimmermann - Confusion of Horizons: Gadamer and the Christian Logos 87-98.

\section{JOURNAL OF EARLY CHRISTIAN STUDIES 9 (2001) nr 1-4:}

J.L. Kovacs - Divine Pedagogy and the Gnostic Teacher according to Clement of Alexandria 3-25; J.W. Trigg - God's Marvelous „Oikonomia”: Reflections of Origen's Understanding of Divine and Human Pedagogy in the Address Ascribed to Gregory Thaumaturgus 27-52; R. Darling YoungEvagrius the Iconographer: Monastic Pedagogy in the „Gnostikos” 53-71; A. Kamesar - Ambrose, Philo, and the Presence of Art in the Bible 73-103; S. Ashbrook Harvey - 2000 NAPS Presidential Address: Spoken Words, Voiced Silence: Biblical Women in Syriac Tradition 105-131; D.H. Williams - Defining Orthodoxy in Hilary of Poitiers" "Commentarium in Matthaeum» 151-171; C. Stewart - Imageless Prayer and the Theological Vision of Evagrius Ponticus 173-204; N.V. Harrison - Women, Human Identity, and the Image of God: Antiochene Interpretations 205-249; S. Ruzer - ,, The Cave of Treasures" on Swearing by Abel's Blood and Expulsion from Paradise: Two Exegetical Motifs in Context 251-271; A. McGowan Marcion's Love of Creation 295-311; P. Gray - Abortion, Infanticide, and the Social Rhetoric of the "Apocalypse of Peter" 313-337; E. Leigh Gibson Jewish Antagonism or Christian Polemic: The Case of the "Martyrdom of Pionius» 339-358; M.R. Salzman - Competing Claims to „Nobilitas” in the Western Empire of the Fourth and Fifth Centuries 359-385; S.J.B. Barnish Religio ,in stagno": Nature, Divinity, and the Christianization of the Countryside in Late Antique Italy 387-402; D. Boyarin - Introduction: JudaeoChristianity Redivivus 417-419; H.I. Newman - Jerome's Judaizers 421-452; D. Brakke - Jewish Flesh and Christian Spirit in Athanasius of Alexandria 453-481 Ch. Elisheva Fonrobert - The "Didascalia Apostolorum»: A Mishnah for the Disciples of Jesus 483-509; S.H. Mratschek - „Multis enim notissima est sanctitas loci": Paulinus and the Gradual Rise of Nola as a Center of Christian Hospitality 511-553; S.J. Shoemaker - Rethinking the „Gnostic Mary”: Mary of Nazareth and Mary of Magdala in Early Christian Tradition 555-595. 
102. THE JOURNAL OF ECCLESIASTICAL HISTORY 52 (2001) nr 1-4: W.H.C. Frend - Church Historians of the Early Twentieth Century: Adolf von Harnack (1851-1930), 83-102.

103. THE JOURNAL OF JURISTIC PAPYROLOGY 31 (2001):

A. Delattre - Un symbol de Nicéee à Deir el-Bahari 7-8; T. Derda-Aurelius Agathodaemon, dekaprôtos of the 2 nd and 3 rd toparchies of the meris of Herakleides and two Tebtynis documents 9-12; T. Derda - The village of Philoxenos: a note 15-16; T. Derda - Pagi in the Arsinoites nome: a study in the administration of the Fayum in the Early Byzantine period (with an appended edition of P. Aberd. 164), 17-31; N. Gonis - Abu and Apa. Arab ononanstics in Egyptian context1) 47-49; T. Górecki - What kind of lamp was the $\sigma \tau \varepsilon \phi \alpha v o$ w mentioned in an ostracon of the $V^{\text {th }}$ century A. D.? 51-53; M.R.M. Hasitzka - Brief des Klostervorstehers Theodoros die AparchêSammlung betreffend 55-58; A. Łajtar - Two Architectural Terms: $\sigma \varkappa o v i \lambda \omega \sigma \iota \varsigma$ and $\sigma \tau \iota \beta \alpha$ s in an Inscription from Murina / el Alamein (with an Appendix: Inscription on a frying-pan) 59-66; E. Wipszycka -

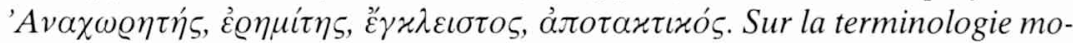
nastique en Egypte 147-168; E. Wipszycka - Le fonctionnement interne des monastères et des laures en Égypte du point de vue économique. À propos d'une publication récente de textes coptes de Bawit 169-186; D.W. Young Shenute's fifth canon in three folios at the National Library in Vienna 187-208.

104. JOURNAL OF THE HISTORY OF IDEAS 62 (2002) nr 1-4:

D.T. Runia - The Idea and the Reality of the City in the Thought of Philo of Alexandria 361-380.

105. JOURNAL OF RELIGIONS ETHICS 29 (2001) nr 1-3:

G. Meilaender - Sweet Necessities: Food, Sex and Saint Augustine 3-18; E. Kaplan Spitz - Sweet Gifts: A Jewish Response to Gilbert Meilaender 19-23; L. Sowle Cahill - Using Augustine in Contemporary Sexual Ethics: A Response to Gilbert Meilaender 25-33; Ch.T. Mathewes - Original Sin and the Hermeneutics of Charity: A Response to G. Meilaender 35-42; G. Meilaender - The Author Replics 43-50; A. Epp Weaver - Unjust Lies, Just Wars? A Christian Pacifist Conversation with Augustine 51-78; G. Scott Davis - A Vindication of Theology. A Response to Alain Epp Weaver 79-85; J. Turner Johnson - Can a Pacifist Have a Conversation with Augustine? A Response to Alain Epp Weaver 87-93.

106. THE JOURNAL OF THEOLOGICAL STUDIES 52 (2001) nr 1-2:

J.S. McLaren - Ananus, James and Earliest Christianity. Josephus Account of the Death of James 1-25; T.D. Barnes - Constantine's Speech to the Assembly of the Saints: Place and Date of Delivery 26-36; J. Warren Smith - Macrina, Tamer of Horses and Healer of Souls: Grief and the Therapy of Hope in Gregory of Nyssa's "De anima et resurrectione» 37-60; I.J. Davidson 
- A Tale of Two Approaches: Ambrose, «De Officiis» 1, 1-22 and Cicero, «De Officiis» 1, 1-6, 61-83; J. Leemans - On the Date of Gregory of Nyssa's First Homilies on the Forty Martyrs of Sebaste (IA and IB) 93-97; S. WesselSocrates' Narrative of Cyril of Alexandria's Episcopal Election 98-104; J. Capper - Two Types of Discipleship in Early Christianity (Review Article) 105-123; J. Carleton Paget - Josephus and Christianity 539-624; S. Parvis - The Canons of Ancyra and Caesarea (314). Lebon's Thesis Revisited 625636; D. Krausmüller - Leontius of Jerusalem, A Theologian of the Seventh Century 637-657; B. Bedingfield - Anglo-Saxons on Fire 658-677.

107. KIELECKIE STUDIA FILOLOGICZNE 14 (2000):

A. Chrobot - „Epitaphium Bionis” Pseudo-Moschosa a „Epitaphium Doralices" Jana Kochanowskiego 9-26.

108. KIRCHE UND ISRAEL 15 (2000) nr 1-2:

T. Ilan - Jüdische Frauen in der Spätantike 7-15; A. Standhartinger - Frauen im Urchristentum 16-25.

109. KRONIKA DIECEZJI RADOMSKIEJ 10 (2001) nr 1-3:

J. Hernoga - Kult obrazów w chrześcijaństwie 213-225.

110. KRONIKA DIECEZJI SANDOMIERSKIEJ 93 (2000) nr 1-8:

J. Krasiński - Męczennik - najbardziej autentyczny świadek 318-321.

111. KWARTALNIK FILOZOFICZNY 29 (2001) nr 1-4:

(Nr 1) J. Wojtysiak - Starożytne początki problematyki istnienia 5-27; M. Manikowski-Grzegorz z Nyssy: filozof, teolog, mistyk. Kłopoty historyka filozofii 133-156.

112. LAÓS 8 (2001) $\mathrm{nr} 1-2$

(Nr 1) A. De Maria - La Chiesa nella teologia africana tra III e IV secolo da Cipriano al Donatismo 11-18; S. Borzì - L'accostamento fra Apollonio di Tiana e Cristo 19-24; G. Calambrogio - Per una identità cattolica: discepoli del Logos 1-5

113. LATERANUM 67 (2001) nr 1-3:

G. Ferraro - Lo Spirito Santo nelle «omelie sui vangeli» di Beda il Venerabile, I: I testi pneumatologici del quarto vangelo 31-69; II: I testi pneumatologici dei Sinottici e di Paolo. Il pensiero di Beda sullo Spirito 291-328; V. Grossi - Nota sulle nozioni di „Tradizione e coscienza storica” nel dibattito moderno sulla storia della Chiesa 115-130; C.L. Rosetti - Alcuni contributi alla teologia eucaristica. Indicazioni bibliografiche 131-148; L. Dattrino L'iniziazione cristiana in Ottato di Milevi 405-422.

114. LITERATURE \& THEOLOGY 15 (2001) nr 1-4:

J.K.A. Smith - Staging the Incarnation: Revisioning Augustine's Critique of Theatre 123-139.

115. LITURGIA SACRA 7 (2001) nr 1-2:

A. Filaber - Powstanie i rozwój twórczości hymnicznej w Kościele od IV do VI wieku 59-69. 
116. LOGOS I ETOS (2001) nr 1-2:

(Nr 1) A. Karaś - Św. Tomasz czyta Boecjusza 152-153.

117. LUMIÈRE \& VIE 50 (2001) nr 249-252:

(Nr 249) P. Gibert - La Parole et l'inscription chrétienne 9-16; ( $\mathrm{Nr} 252)$ M. Canévet - Jalons pour une pratique du discernement spirituel: l'expérience de l'Église aux III et $I V^{e}$ siècles 33-42.

118. LA MAISON DIEU (2001) nr 225-228:

( $\mathrm{Nr} 226)$ P. Yousif - Parole et silence chez saint Éphrem de Nisibe 95-114; (Nr 227) G. Madec - L'École du Christ. Menus propos sur la prédication d'Augustin 67-78.

119. MANKIND QUARTERLY 41 (2001) nr 3:

$\mathrm{Ph}$. Thornhill - The Continental Cult of St. Alban 291-306.

120. MEANDER 56 (2001) nr 1-2:

K. Korus - Życie praca i służbą. Profesor Mieczysław Brożek (1911-2000), 3-8; D. Brodka - Idea „imperium sanctum” w panegiryku Koryppusa na Justyna II, 95-102.

121. MEDIEVAL ENCOUNTERS 7 (2001) nr 1-3:

C. Lo Nero - „Christiana Dignitas”: New Christian Criteria for Citizenship in the Late Roman Empire 146-164.

122. MÉLANGES DE L'ÉCOLE FRANÇAISE DE ROME 113 (2001) nr 1 (Moyen Âge):

S. Rota - Teodorico il grande fra „Graecia” e „Ausonia”. La rappresentazione del re ostrogotico nel "Panegyricus» di Ennodio 203-243; S. GioanniLa contribution épistolaire d'Ennode de Pavie à la primanté pontificale sous le règne des papes Symmaque et Hormisdas 245-268.

123. MÉLANGES DE SCIENCE RELIGIEUSE 58 (2001) nr 1-4:

( $\mathrm{Nr} 1) \mathrm{B}$. Fauvarque - La représentation du millenium dans quelques manuscripts médiévaux de l'Apocalypse 5-21; M.P. Baudienville - Iconographie de l'Apocalypse et histoire de l'art 23-37; ( Nr 2) Ch. Cannuyer - L'inedité des sarabaïtes, ces moines d'Égypte que méprisait Jean Cassien 7-19.

124. MELITA THEOLOGICA 52 (2001) nr 1-2:

J. Lupi - God and the Trinity in the Fathers (II), 67-100; M. Attard - Is a painted icon monastic? 197-203.

125. MEMORANDA 75 (2001) nr 1-4:

K. Grzesiak - Kościót Etiopski. Dzieje, specyfika dogmatyczna i obrzędowa, stan aktualny 156-171.

126. METRAŠTIS (2001) nr 19:

R. Siniškevičiūtė - Kolizijos tarp ankstyrosios krikščionybès ir Romos imperijos Antoninu ir Severu valdymo metais (138-235 m.), 81-149.

127. MIEJSCA ŚWIĘTE 30 (2001) nr 1-12:

(Nr 11) I. Szymczak - Pielgrzymka do raju (Armenia) 13-19; K. Renik - Od profanum do sacrum 20-24; J.S. Partyka - Dziedzictwo Abgara 25-28; 
J.S. Partyka - Literatura Ormian 40-41; (Nr 12) M.M. Matusiak - Tajemniczy opiekun (św. Mikotaj) 10-13; W. Chrostowski - Miasto dobroczynności (Myra) 14-19; J.S. Partyka - Mikołaj-Święty Wschodu i Zachodu 20-27. 128. MITTEILUNGEN DES INSTITUTS FÜR ÖSTERREICHISCHE GESCHICHTSFORSCHUNG 108 (2000) nr 1-4:

H.H. Anton - Troja-Herkunft, „origo gentis” und frühe Verfaßtheit der Franken in der gallisch-fränkischen Tradition des 5. bis 8. Jahrhunderts 1-30. 129. MITTELLATEINISCHES JAHRBUCH 36 (2001) nr 1-2:

R. Krüger - Ein Mythos der Moderne: Der Erdscheibentheorie im Mittelalter und die Verfälschung des "Hexaemeron" des Basilius von Caesarea durch Bernard de Montfaucon (1706), 3-29.

130. MNEMOSYNE 54 (2001) nr 1-6:

Th. Gärtner - Das Vogelprodigium im Helena - Epyllion des Dracontius: Antike Vorbilder und mittelalterliches Nachleben 345-349; G. van der Kraan - Juvenal I 3, 10-20: The Location of Egeria's Abode 472-475; D. Woods „Veturius” and the Begining of the Diocletianic Persecution 587-589.

131. MONASTICA 42 (2001) nr 1-4:

J. Angelini - „Virtus in infirmitate”. Virtù monastiche in un tempo frantumato prezioso antiquariato o esercizio di conversione all'Evangelo? ( $\mathrm{nr} 1)$ 17-30; (nr 2) 19-31; (nr 3) 18-30; (nr 4) 30-44; (Nr 2) A. Nocent - San Benedetto e la liturgie 37-43.

132. MORALIA 24 (2001) nr 1-4:

M. Raczkiewicz - Vox Patrum. La voz de los Padres en el estudio de la moral 173-198.

133. MÓWIĄ WIEKI (2001) nr 1-12:

(Nr 1) M. Poprzęcka - Neron czy chrześcijanie 49-52; (Nr 4) M.B. Leszka Agrypina Młodsza 46-49; (Nr 6) R. Suski - Piorun, cesarz i poganin (cesarz Karus) 6-10; M.J. Leszka - Faustyna Młodsza, żona Marka Aureliusza 4445; (Nr 7) M.J. Leszka - Galla Placydia, cesarzowa upadającego imperium 43-48; (Nr 9) M.B. Leszka - Atenais-Eudokia, córka filozofa 45-49; (Nr 11) T. Ginter - Rzym z czasów Nerona 44-47; (Nr 12) E. Wipszycka - Boże Narodzenie. Dlaczego święcimy je 25 grudnia 6-11; M.J. Leszka - Julia Domna, Matka Ojczyzny 51-52.

134. MÜNCHENER THEOLOGISCHE ZEITSCHRIFT 52 (2001) nr 1-4:

R. Kaczyński - Die Absage an das Böse in der Feier der christlichen Initiation 220-233.

135. LE MUSÉON 114 (2001) nr 1-2:

G. Robinson Schenke - A Plea for Gender Equality in a Partially Restored Coptic Codex (Papyrus Berolinensis 20915) 15-39; R. Charron - L. Painchaud - „God is a Dyer”. The Background and Significance of a Puzzling Motif in the Coptic "Gospel According to Philip» (CG II, 3) 41-50; M. van Esbroeck - Alexandre à Amasée: Un épisode peu remarqué 141-152; 
A. Topchyan - Julius Africanus' "Chronicle» and Movsēs Xorenac 'i 153-186;

B. Outtier - Le Dogmatikon d'Arsène d'Iqalto et ses modèles grecs 217-226. 136. MUSEUM HELVETICUM 58 (2001) nr 1-4:

D.G. Piccardi - Afrodite al Telaio. Una leggenda cipriota in Nonno 169-175; M. Puelma - Eine neue Lesart zu Augustinus «C. Faust» 30, 9, p. 545, 27, s. 176; A. Papathomas - „Keine Bestie auf der Welt gleicht der schlechten Frau". Frauenfeindliche Polemik aus der ps-chrysostomischen Homilie «In decollationem Praecursoris» in einem Berliner literarischen Papyrus 46-53.

137. MYSTICS QUARTERLY 27 (2001) nr 1-4:

D. Griggs - Symeon the New Theologian's Doctrines on Dispassion 9-26. 138. NEUE ZEITSCHRIFT FÜR MISSIONSWISSENSCHAFT 57 (2001) nr 1-4:

G. Schelbert - Zur frühen Missionsgeschichte 3-14.

139. NEW TESTAMENT STUDIES 47 (2001) nr 1-4:

J.M. Robinson - Ch. Heil - The Lilies of the Field: Saying 36 of the "Gospel of Thomas" and Secondry Accretions in Q 12. 226-31, 1-25; S.C. Carlson Clement of Alexandria on the ,order” of the Gospels 118-125; T. Nicklas Die 'Juden' im Petrusevangelium (PCair 10759) Ein Testfall 206-221; F. Bovon - Names and Numbers in Early Christianity 267-288; M.M. Mitchell - A Patristic Perspective on Pauline periautologa 354-371; P.J. Williams - Some Problems in Petermining the „Vorlage” of Early Syriac Versions of the NT 537-543.

140. NOMOS (2000/2001) nr 30-36:

(Nr 34/36) P. Ibek - Stoicyzm. Wędrówka idei przez religie 109-128.

141. NOTITIAE 37 (2001) nr 414-423:

M. Hanke - Il Diaconato femminile: osservazioni sul recente dibattito 195239; N. Giampietro - In Memoriam. Adalbert Gautier Hamman OFM (1910-2000) 554-555.

142. NOUVEAUX CAHIERS MARIALS (2001) nr 61-64:

Nr 63: Des Apocryphes parlent de Marie (cały zeszyt).

143. NOVA \& VETERA 76 (2001) nr 1-4:

(Nr 2) G. Emery - L'image du Christ: le concile de Nicée II, 17-30; (Nr 3) Ph. Caspar - Aux origines d'une Tradition: culture de vie, culture de mort chez les Pères apostoliques 55-65.

144. NOVUM TESTAMENTUM 43 (2001) nr 1-4:

D.M. Scholer - Bibliographia Gnostica: Supplementum II/4, 39-88; T. Baarda - The 'Foolish' or 'Deaf'Fig-Tree: Concerning Luke 19:4 in the "Diatessaron» 161-177; S.C. Mimouni - Qui sont les Jesséens dans la notice 29 du "Panarion» d'Épiphane de Salamine? 264-299; P.J. Williams - Bread and the Peshitta in Matthew 16, 11-12 and 12, 4, 331-333; V.K. Plisch - Die Perikopen über Johannes den Täufer in der neuentdecken mittelägyptischen Version des Matthäus-Evangeliums (Codex Schфyen) 368-392. 
145. NOWY FILOMATA 5 (2001) nr 1-4:

(Nr 1) G. Czochara - Oktawiusz Minucjusza Feliksa-mity i fakty retorycznej konfrontacji chrześcijan i pogan 39-50; (Nr 2) M. Myczkowski - Rzym ofiar i prześladowców 105-110; C. Kałużny - Stosunki Kościoła z państwem rzymskim na przyktadzie prowincji Afryki Pótnocnej (II-IV wiek) 111-124; (Nr 3) S. Stabryła - Wpływ kultury antycznej na cywilizację średniowiecznej i nowożytnej Europy 225-240; (Nr 4) S. Stabryła - Kultura polska wobec tradycji antycznej, 283-303; M. Karas - Życie Nestoriusza, patriarchy Konstantynopola $(V$ w.) 263-271.

146. NUMEN 48 (2001) nr 1-4:

P. Hubai - Über die Ursachen des Sieges des Christentums in Ägypten 81124; M.W. Dickie - Exclusions from the Catechumenate: Continuity or Discontinuity with Pagan Cult? 417-443; C. Giuffré Scibona - How Monotheistic is Mani's Dualism? 444-467.

147. NUNTIUM 5 (2001) nr 14-15:

(Nr 15) D. Nothomb - Un piccolo popolo e le due città di Sant'Agostino 27 29.

148. OBNOVLJENI ŽIVOT 56 (2001) nr 1-4:

Lj. Mokrović - Uzajamni utjecaj kršćanstva i umjetnosti na zajednićkom povijesnom putovanju (I. dio). Od ranokršćanstva do ranog srednjeg vijeka 79-102; S. Kos - Kristova obnova ženidbe u spisima Klementa Aleksandrijskoga 471-494.

149. OEUVRES ET CRITIQUES 26 (2001) nr 2:

Ch. Perrot - Les sources canoniques et extra-canoniques sur Jésus 197-211. 150. ORIENS CHRISTIANUS 84 (2000):

S. Heid - Zwei an den Enkainien der Jerusalemer Grabeskirche gehaltene Predigten des griechischen Ephräm 1-22; M. Kohlbacher - Ein vergessener geistlicher Vater (Palästina $5 \mathrm{Jh}$ ?). Anmerkungen zu Pseudo-MakariosBriefen (CPG 2415, 5) 23-53; M. Illert - Zur Motivierung und Deutung des Askese bei Pseudomakarios 54-58; E.E. Knudsen - An Important Step in the Revival of Literary Syriac Abrahom Nuro's "Tawldotho» 59-65; S. Khalil Samir - Georg Graf (1875-1955), sa bibliographie et son rôle dans le renouveau des études arabes chrétiennes 77-100; P.O. Scholz - Nubisches Christentum im Lichte seiner Wandmalerein 178-231.

151. ORIENTALIA CHRISTIANA ANALECTA 264 (2001):

C. Gugerotti - La liturgia armena delle ordinazioni e l'epoca ciliciana. Esiti rituali di una teologia di comunione tra Chiese 1-394.

152. ORIENTALIA CHRISTIANA PERIODICA 67 (2001) nr 1-2:

M. Stavrou - Le premier traité sur la procession du Saint-Esprit de Nicéphore Blemmydès 39-141; L. Mariès - F. Graffin - Monseigneur René Graffin (1858-1941): histoire de sa familie, de sa Patrologie Orientale et de ses collaborateurs 157-170; S. Hillyer Levitt - Where Does „Barlaam and Jo- 
saphat" Take Place? 263-273; R.F. Taft - Byzantine Communion Rites II: Later Formulas and Rubrics in the Ritual of Clergy Communion 275-352; S. Heid - Ephraem Graeci homilia de iudicio et pretiosa cruce (CPG 4105) 353-370; R.C. Hill - Chrysostom on the obscurity of the Old Testament 371383; L.S.B. MacCoull - P. Lond. Copt. I 1077: Taxes in Money in Seventhcentury Egypt 385-436; M. Amerise - La scrittura e l'immagine nella cultura tardoantica: il caso di Abgar di Edessa 437-445.

153. ORIENTE CRISTIANO 40 (2000) nr 3-4:

(Nr 3) D. Giordano - Aspetti del monachesimo bizantino in Sicilia 3-24; (Nr 4) J. Samaha - Maria nella concezione bizantina 24-31.

154. ORTHODOXES FORUM 15 (2001) nr 1-2:

Th. Nikolau - „Du sollst dir kein Gottesbild machen”. Die Undarstellbarkeit Gottes bzw. der Heiligen Trinität 5-15; R. Novotný - Theological Methods in Gregory Nazianzen's five Theological Orations 17-30; F. Gahbauer - Die „Quelle”: ein aussagenreiches Sprachbild in der Theologie der Kirchenväter 157-172.

155. OSTKIRCHLICHE STUDIEN 50 (2001) nr 1-4:

J. Rist - Jakob Speigl: Biogramm und Bibliographie 5-9; A. Rudolph Abraham in Justins Dialog mit dem Juden Tryphon 10-33; J. Rist - Ein spätantikes Plädoyer für den Psalmengesang: Niceta von Remesiana und seine Schrift «De psalmodiae bono» (CPL 649), 34-57; J. Hofmann - Brückenbauerinen zwischen Byzanz und dem Westen. Forschungsbericht über den vergessenen Beitrag byzantinischer und westlicher Christinnen der byzantinischen Ära zur Verständigung zwischen ihren Kirchen und Völkern (330-1453), 58-78; E.M. Synek - 1000 Jahre Erfahrungstheologie: Symeon der Neue Theologe 79-105.

156. PÂQUE NOUVELLE 29 (2000) nr 1-4:

Ph. Caspar - La dimension cosmique du sacrement du Corps du Christ (I): L'Eucharistie chez saint Augustin 15-24; M. Dangoisse - Nos Pères dans la foi. Comment Augustin désigna son successeur 45-53;

157. PASTORES (2001) nr 10-13:

(Nr 10) J. Naumowicz - Który człowiek bogaty może być zbawiony? 93-99; (Nr 12) J. Naumowicz - Jak tworzyć więź z ludźmi 94-102.

158. PEDAGOGIA CHRISTIANA 2001, nr 1(7):

W. Filarski - Clonmacnois - klasztor św. Kierana - z pedagogii monastycyzmu irlandzkiego VI wieku 81-88.

159. PENSAMIENTO 57 (2001) nr 217-219:

J.A. Moreno - Trascendimiento y autotrascendimiento en la teoría del conocimiento agustiniana 471-479.

160. PHILOSOPHISCHE RUNDSCHAU 48 (2001) nr 1-4:

Ch. Horn - Philosophie des Geistes bei Augustinus 97-115.

161. PHILOLOGUS 145 (2001) nr 1-2: 
S. Reece - The Epithet åoíoouos in Nonnus" "Dionysiaca» 357-359. 162. PHOENIX 55 (2001) nr 1-2:

S. Goins - Boethius "Consolation of Philosophy» 1.2.6. and Virgil Aeneid 2: Removing the Clouds of Mortal Anxieties 124-136; T.D. Barnes - Monotheists All? (Review Article) 142-162.

163. POLONIA SACRA 5 (2001) nr 8-9:

(Nr 8) W. Kic - Korynt w epoce Pawta Apostoła 91-132; (Nr 9) T. Klibengajtis - Problematyka metanoi $w$ «Stromatach» Klemensa Aleksandryjskiego 5-50; D. Kasprzak - Znaczenie teologiczne koncepcji cierpliwości u św. Hilarego z Poitiers 51-78; P. Zarębski - Nędzne ziarno. Ciało, pleć, matżeństwo w myśli św. Grzegorza z Nyssy 79-88.

164. POSITIONS LUTHÉRIENNES 49 (2001) nr 1-4:

G. Siegwalt - Arménie: dix-sept siècles de christianisme 257-264; Ch. Adjémian - La pensée théologique de l'Église apostolique arménienne 265-279. 165. POZNAŃSKIE STUDIA TEOLOGICZNE (2001) nr 10-11:

(Nr 10) Św. Cezary z Arles - Testament, tłum. A. Strzelecka, wstęp P. Wygralak 73-78; A. Swoboda - Postawa Ojca wobec dziecka w pismach Plutarcha z Cheronei i autorów chrześcijańskich IV wieku (Ambroży, Augustyn, Hieronim) 79-96; P. Wygralak - Formacja biblijna dziewic i mnichów w klasztorach hiszpańskich VI-VII wieku 97-110; (Nr 11) E. Adamiak - Kobieta w Kościołach $i$ wspólnotach chrześcijańskich. Próba syntezy teologicznej 91-114.

166. PREMISLIA CHRISTIANA 9 (2001):

J. Edling - Rewelatywno-temporalna struktura świata w ujęciu św. Augustyna 175-188.

167. PRESENZA PASTORALE 70 (2000) nr 1-4:

(Nr 4) J.P. Lieggi - L'Eucaristia in San Gregorio di Nazianzeno 45-87.

168. PRO ECCLESIA 9 (2000) $\mathrm{nr}$ 3-4:

J.T. Lienhard - Origen And The Crisis Of The Old Testament In The Early Church 355-366; S.R. Holman - The Entitled Poor. Human Rights Language in the Cappadocians 476-489.

169. PRO ECCLESIA 10 (2001) nr 1-4:

K. Anatolios - The Immediately Triune God: A Patristic Response to Schleiermacher 159-178; R.L Wilken - Doctores Ecclesiae Interpreting Job Allegorically: The «Moralia» of Gregory the Great 213-226; A.G. Cooper St. Maximus The Confessor on Priesthood, Hierarchy and Rome 346-367.

170. PROCHE ORIENT CHRÉTIEN 50 (2000) nr 3-4:

Jean Chrysostome - Le chrétien, un être solidaire (PG 54, 623-624), trad. J.M. Magnin 227-228; P. Figueras - Palestinian Monasticism in the Early Muslim Period 229-245; Y. de Andia - Le monastère de Saint-Sabas à Rome: Relations théologiques entre l'Orient et l'Occident aux VII et VIII siècles 279-296. 
171. PRZEGLĄD POWSZECHNY 118 (2001) nr 1-12:

(Nr 5) M. Blaza - 1700-lecie chrześcijaństwa w Armenii 253-255; (Nr 7-8) Modlitwa św. Efrema Syryjczyka (Sermo de Confessoribus), thum. R. Zarzeczny 11; D. Kowalczyk - O Komunii św. na rękę, czyli mówić tak, by nic nie powiedzieć 13-25; ( $\mathrm{Nr} 9)$ Anqasa byrhan, czyli Brama świattości (fragm. Hymnu ku czci NMP z księgi Me'eraf, PO 34, 69), tłum. R. Zarzeczny 177; (Nr 10) Gnostycka modlitwa dziękczynna z Nag Hammadi, tłum. R. Zarzeczny 9-10.

172. PRZEGLĄD RELIGIOZNAWCZY (2001) nr 199-202:

(Nr 202) A. Ługiewicz - Antyczna magia i religie 3-18.

173. QUESTIONES LITURGIQUES 82 (2001) nr 1-4:

J. Leemans - Celebrating the Martyrs: Early Christian Liturgy and the Martyr Cult in Fourth Century Cappadocia and Pontus 247-267.

174. QUAESTIONES SELECTAE 8 (2001) nr 12-13:

(Nr 13) C.M. Paczkowski - Teologia świadectwa i doświadczenia $w$ «Katechezach» Cyryla Jerozolimskiego 51-73.

175. RECHERCHES AUGUSTINIENNES 32 (2001):

A. Jakab - Denys d'Alexandrie: réexamen des données biographiques... 3-37; J.N. Guinot - L'«Expositio rectae fidei» et le traité "Sur la Trinité et l'Incarnation" de Théodoret de Cyr: deux types d'argumentation pour un même propos? 39-74; M. Dulaey - La figure de Jacob dans l'exégèse paléochrétienne (Gn 27-33), 75-168; S. Toulouse - Que le vrai sacrifice est celui d'un coeur pur. À propos d'un oracle „porphyrien" (?) dans le "Liber XXI sententiarum» édité parmi les oeuvres d'Augustin 169-223; C. Mertens Saint Augustin et les dernières années de Charles Du Bos 225-270.

176. RECHERCHES DE SCIENCE RELIGIEUSE 89 (2001) nr 1-4:

I. Bochet - Variations contemporaines sur un théme augustinien: l'énigme du temps 43-66.

177. REFORMED THEOLOGICAL REVIEW 60 (2001) nr 1-3:

D.W. Jowers - Divine Unity and the Economy of Salvation in the «De Trinitate» of Augustine 68-84.

178. RELIGION \& LITERATURE 33 (2001) nr 3:

G.L. Bruns - The Senses of Augustine (On Some of Lyotard's Remains) $1-23$.

179. RELIGIONI ET LITTERIS (2001) nr 1:

J. Ratzinger - Chrześcijańskie zwycięstwo rozumu nad światem religii. Przyszłość chrześcijaństwa w perspektywie Ojców Kościoła, tłum. J. Królikowski 91-104.

180. REVIEW FOR RELIGIOUS 60 (2001) nr 1-6:

J.L. Franck - Apostolic Community in the Assumptionist (Augustinian Tradition) 171-178.

181. REVISTA AGUSTINIANA 42 (200) nr 127-128: 
P. Laurence - Eglise, temmes et pouvoir dans les «Actes de Thomas»193220; S.J.G. Sánchez - La tradition du textes du «Dialogue avec Triphon» de Justin Martyr (I) 221-262; (II) 653-714; J.V. Ganzarolli de Oliveira - San Agustín: lenguaje y alegoría 263-275; M. Ángeles Navarro Girón - La "Ciudad de Dios» de San Agustín. Materiales para el estudio (VI) 277308; J. Domingues - E. Gala - P. Gomes - Santo Agostinho na Cultura Portuguesa. Contributo bibliográfico 321-409; M. Ángeles Navarro Girón Finitud y finalidad. Releyendo La «Ciudad de Dios» de San Agustín 841-877.

182. REVUE BÉNÉDICTINE 111 (2001) nr 1-4:

G. Partoens - La collection de sermons augustiniens „De verbis Apostolis”. Introduction et liste des manuscripts les plus anciens 317-352; F. DolbeauSept sermons antiques, tires d'un homéliaire latin d'Olomouc 353-398; M. Gorman - The Canon of Bede's Works and the World of Ps. Bede 399-445; P.I. Fransen - Le dossier patristique d'Hélisachar le manuscrit Paris, BNF lat. 11574 et l'une de ses sources 464-482.

183. REVUE BIBLIQUE 108 (2001) nr 1-4:

É. Puech - Notes d'épigraphie christo-palestinienne cisjordanienne 61-72; S.J.G. Sanchez - Du bénéfice de «De Resurrectione» 73-100.

184. REVUE DE L'HISTOIRE DES RELIGIONS 218 (2001) nr 1-4:

C. et F. Jullien - „Aux temps des disciples des apotres”. Les sabbatiens d'Édesse 153-170.

185. REVUE DE MÉTAPHYSIQUE ET DE MORALE (2001) nr 2:

L. Devillairs - La Première Méditation de Descartes et le «De beata vita» d'Augustin 119-132.

186. REVUE DE QUMRAN 19 (2000) nr 75-76:

(Nr 76) D. Dimant - Resurrection, Restoration and Time-Curtailing in Qumran, Early Judaism, and Christianity 527-548.

187. REVUE DES ÉTUDES AUGUSTINIENNES 47 (2001) nr 1-2:

A. Daguet-Gagey - Septime Sévère, un empereur persécuteur des Chrétiens? 3-32; Y. Duval - Celerinus et les siens d'après la correspondance de Cyprien (Ep. 21-23, 37, 39), 33-62; F. Chapot - Prière et sentiment religieux chez Firmicus Maternus 63-83; P. van Nuffelen - Les «Lettres festales» d'Athanase d'Alexandrie: les ,erreurs” chronologiques de l',Index syriaque” 85-95; F. Gautier - Le carême de silence de Grégoire de Nazianze: une conversion à la literature? 97-143; F.B.A. Asiedu - Paul and Augustine's Retrospective Self: The Relevance of «Epistula» XXII, 145-164; A.A. Nagy La forme originale de l'accusation d'anthropophagie contre les chrétiens, son développement et les changements de sa représentation au II siècle 223-249; Y. Duval - La ,plebs” chrétienne au ,siècle de Cyprien” jusqu'à la paix de l'Église (1), 251-282; Y.M. Duval - La place et l'importance du Concile d'Alexandrie ou de 362 dans l'«Histoire de l'Église» de Rufin d'Aquilée 
283-302; M.M. Gorman - The Manuscript Tradition of Augustine's «De Genesi contra Manichaeos» 304-311; V.H. Drecoll - „Etiam posteris aliquid profuturum". Zur Selbststilisierung bei Augustin und der Beeinflussung der eigenen Wirkungsgeschichte durch Bücher und Bibliothek 313335; N. Duval - Encore sur l'apparition et l'usage de l'indiction en Afrique 337-355.

188. REVUE DES SCIENCES PHILOSOPHIQUES ET THÉOLOGIQUES 85 (2001) nr 1-4:

$\mathrm{K}$. Verrycken - La métaphsique d'Ammonius chez Zacharie de Mytilène 241-266; R. Chiaradonna - Proclus et la théologie platonicienne 287-298.

189. REVUE DES SCIENCES RELIGIEUSES 75 (2001) nr 1-4:

M. Canevet - L'unicité de la foi comme fondement de la communion dans l'Église: Athanase et la controverse autour de Nicée 68-76; J.M. Vercruysse Les Pères l'Église et Lucifer 147-174; P. Mattei - Regards inactuels sur une Église en mutation. Tertullien et les paradoxes de son ecclésiologie 275-287; A. Faivre - Préceptes laïcs et commandements humains. Les fondements scripturaires de 1 Clément 40, 5, 288-308; G. Rémy - La grâce du logie (suite) 309-337; B. Sesboüé - Tout récapituler dans le Christ. Christologie et sotériologie d'Irénée de Lyon 380-382.

190. REVUE D'HISTOIRE DE L'ÉGLISE DE FRANCE 87 (2001) nr 218219:

M. Heijmans - Césaire d'Arles, un évêque et sa ville 5-25; $\mathrm{H}$. Noizet - Les basiliques martyriales au VI et au début du VII siècle 329-355.

191. REVUE D'HISTOIRE ET DE PHILOSOPHIE RELIGIEUSES 81 (2001) $\mathrm{nr} 1-4$ :

A. Caquot - Poésie religieuse de Qumrân 131-137; J.M. Prieur - „Si vous ne faites pas ce qui est à droite comme ce qui est à gauche”. Crucifixion et renversement des attitudes dans la littérature chrétienne ancienne 413-424.

192. REVUE THÉOLOGIQUE DE LOUVAIN 32 (2001) nr 1-4:

R. Gryson - „Enfanter un esprit de salut”. L'interprétation de Isaie 26, 17-18 chez les Pères grecs 189-217; P.M. Bogaert - Les Quatre Vivants, l'Évangile et les évangiles 457-478.

193. RHEINISCHES MUSEUM FÜR PHILOLOGIE 144 (2001) nr 1-4:

J. Dochhorn - Vegetationskult in der Urzeit. Euseb, H.E. 1, 10, 6-7 und die Anfänge der Kultur - und Religionsgeschichte bei Philo von Byblos 397-429.

194. RICERCHE STORICO BIBLICHE 13 (2001) nr 1-2:

( $\mathrm{Nr}$ 1) A. Passoni dell'Acqua - Il divenire del testo Greco 105-132; T. Stramare - Il cammino della sacra Scrittura nella tradizione testuale latina 133-152; P.G. Borbone - L'origine e lo sviluppo testuale della versione siriaca dell'Antico Testamento "Peshitta» 153-164; (Nr 2) Gli Atti degli Apostoli. Storiografia e biografia 1-170.

195. RICERCHE TEOLOGICHE 11 (2000) nr 1-2: 
(Nr 1-2) A. Mitescu - La liturgia orale dei cristiani sotto Traiano secondo l'interrogatorio di Plinio il Giovane 9-54; F. Franco - Gnosi cristiana e gnosticismo: attualità di un confronto 55-92; W. Turek - Petrus fundamentum dicitur. Alcune osservazioni su "Il mistero dell'incarnazione del Signore» 4, 27-33 di Ambrogio 145-154; V.D. Muro - Communione ecclesiale e Roma nel "De sacramentis» di Ambrogio di Milano 155-166.

196. RICERCHE TEOLOGICHE 12 (2001) nr 1-2:

(Nr 1) J.B. Nsuka - Misericordia Dei in Cipriano di Cartagine. Da Dio indulgente al peccatore riconciliato 193-202; (Nr 2) E. Giannarelli - „Credo nello Spirito Santo". L'assioma conciliare „lettura storico-patristica” 51-85; E. Dal Covolo - „Credo nello Spirito Santo”. A proposito della „lettura storico-patristica” dell'assioma conciliare 87-90.

197. RIVISTA BIBLICA 49 (2001) nr 1-4:

C. Termini - La creazione come à@xí della legge in Filone di Alessandria 183-318.

198. RIVISTA DI ARCHEOLOGIA CRISTIANA 76 (2000) nr 1-2:

V. Fiocchi Nicolai et alii - L'ipogeo di „Roma Vecchia” al IV miglio della via Latina. Scavi e restauri 1996-1997, 3-179; F. Bisconti - Pastori eccezionali. A proposito di due affreschi catacombali romani recentemente restaurati 181-216; C. Salvetti - B. Mazzei - Il sarcofago attico degli Amorini a Pretestato. Restauro e nuove considerazioni iconografiche 217-242; L. Spera - Un sarcofago con temi agro-pastorali dallo scavo dell'arenario centrale della catacomba di Priscilla 243-284; C. Angelelli - La chiesa titolare dei SS. Marcellino e Pietro. Una revisione sulla base di nuovi documenti 287-350; J. Biarne - Le monachisme dans les îles de la Méditerranée nord-occidentale 351-374; F. Cristini-Alle origini della parocchia rurale nel Molise: prime Testimonianze di edifici di culto nell'area della diocesi di Trivento 375-404; F. di Renzo - Alle origini della parocchia rurale nel territorio dell'antica diocesi di Valva 405-427; N. Duval - Les relations entre l'Afrique et l'Espagne dans le domaine liturgique: existe-t-il une explication commune pour les „contre-choeurs”? 429-476; C. Ebanista - La basilica „nova” di Cimitile/Nola. Gli scavi del 1931-36, 477-539; F. Fei - Marche. Riflessioni sull'organizzazione pievana 541-553; A. Ben Abed - M. Bonifay - M. Tixot - S. Roucole - Les basiliques chrétiennes de Sidi Ididi 555-587; E. Fosszle - Le indizioni nell'epigrafia cristiana 589-599; M. Perraymond Riflessioni iconografiche sul coperchio del cosiddetto sarcofago di S. Sotere in Callisto 601-620; B. Mazzei - F. Severini - Il fenomeno monastico nelle isole minori del mar Tirreno dal IV al IX secolo. Fonte letterarie ed evidenze archeologiche 621-650; Ph. Pergola (red.) - Archeologia e cultura della tarda antichità e dell'alto medioevo. Resoconto delle sedute dell'A.A. 1998-1999, 651-682.

199. RIVISTA DI ARCHEOLOGIA CRISTIANA 77 (2001) nr 1-2: 
F. Bisconti - D. Nuzzo - Scavi e restauri nella regione della „Velata” in Priscilla 7-95; R. Giuliani et alii - Nuove indagini nella catacomba della ex vigna Chiaraviglio sulla via Appia antica. Relazione delle campagne di scavo nella regione F (1997/1999), 97-362; M. Buonocore - Un "titulus” cristiano da „Hortona” (Abruzzo) 365-369; S. Cisci - Il culto dei martiri sardi in Sardegna in età tardoantica e altomedievale attraverso le testimonianze storiche ed archeologiche 371-406; M. de Martino - Sul significato del termine $\sigma \tau \dot{\eta} \lambda \eta$ in un'iscrizione onoraria di età teodosiana 407-417; N. Duval - Le monuments chrétiens d'Haïdra: recherches récentes 419-467; C. Godoy - Sobre arqueología y liturgia en las iglesias hispanas 469-480; M.Y. PerrinLa paternité du Christ. À propos d'une mosäque de la catacombe de Domitille 481-518; M. Sapelli - Sarcofagi tardoantichi e paleocristiani del Museo Nazionale Romano in Palazzo Massimo alle Terme 519-543; G. Spinola - I sarcophagi paleocristiani del Museo Pio Cristiano ex Lateranense nei Musei Vaticani 545-569; Ph. Pergola (red.) - Archeologia e cultura della tarda antichità e dell'alto medioevo. Resconto delle sedute dell'A.A. 1999. 2000, 573-594.

200. RIVISTA STORICA ITALIANA 112 (2000) nr 1-3:

A. Giuliano - L'arco di Costantino come documento storico 441-474; L. Martincic - Iconografia del Davide musico nella miniatura medievale dall'VIII al XIII secolo 475-509; G. Bowersock - Burckhardt sulla Tarda Antichità: dal „Constantin” alla „Griechische Kulturgeschichte” 1094-1108; L. Cracco Ruggini - Le trasformazioni dell'Urbs Roma fra IV e VI secolo (a proposito di un libro recente) 1109-1120.

201. ROCZNIKI TEOLOGICZNE 48 (2001) nr 1-9:

(Nr 2: Teologia dogmatyczna) H. Witczyk - Diakoni w Kościele apostolskim 19-32; J. Pałucki - Biskup-prezbiter-diakon w refleksji Ojców Kościoła 3353; (Nr 4: Historia Kościoła) P. Szczur - Aretologia agapetyczna Klemensa Aleksandryjskiego $w$ zarysie 5-35; M. Ziółkowska - Maryja napetniona Duchem Świętym - ideałem cnót w «Wykładzie Ewangelii według św. Eukasza» św. Ambrożego 37-51; (Nr 5: Teologia Duchowości) J. Misiurek Historyczne zjednoczenie z Bogiem według św. Grzegorza z Nyssy (394) 113-123; (Nr 9: Teologia fundamentalna i Religiologia) Z. Krzyszowski Kościót a kultura w pierwszych wiekach chrześcijaństwa 53-68.

202. ROCZNIKI TEOLOGICZNE WARSZAWSKO-PRASKIE 1 (2001):

Memoriat Orozjusza, kapłana hiszpańskiego, do św. Augustyna, biskupa Hippony w sprawie błędów pryscylian i orygenistów, tłum. i opracowanie K. Obrycki 91-106.

203. ROMISCHE QUARTALSCHRIFT 96 (2001) nr 1-4:

A. Merkt - Symbolum. Historische Bedeutung und patristische Deutung des Bekenntnisnamens 1-36; S. Heid - Die gute Absicht im Schweigen Eusebs über die Kreuzauffindung 37-56. 
204. SACRA DOCTRINA 46 (2001) nr 1-6:

(Nr 6) P.M. Calaon - Gesù Cristo, vero Dio e vero uomo nella „confessio fidei" gallicana 29-54; A. Carpin - La preghiera in Isidoro di Siviglia 55-114; P. Magnanini - I musulmani in Sicilia 148-157.

205. SACRIS ERUDIRI 40 (2001):

D. Rankin - Tertullian's Vocabulary of the Divine Individual's in "Adversus Praxean» 5-46; L. Karafiková - Die Unendlichkeit Gottes und der unendliche Weg des Menschen nach Gregor von Nyssa 47-81; W. Mayer - At Constantinople, how often did John Chrysostom preach? Addressing assumptions about the workload of a bishop 83-105; R.C. Hill - Theodore of Mopsuestia, interpreter of the prophets 107-129; A.P. Orbán - Ein anonymer Aratorkommentar in Hs. London, Royal MS. 15 A.V. Editio princeps, Teil II (Arator, "Historia apostolica» 1,515-2,1250), 131-229; D.Ó. Cróinín - A New Seventh-Century Irish Commentary on Genesis 231-165; P. Verkest - The „praefatio" of the Irish "Eclogae tractatorum in psalterium» 267-292; D.Tj. Sieswerda - The $\Sigma \omega \tau$ inoıos, the original of the Izbornik of 1073, 293-413.

206. SAECULUM CHRISTIANUM 8 (2001) nr 1-2:

(Nr 1) T. Kołosowski - Sprawa Pryscyliana. Wspótpraca episkopatu hiszpańskiego z władza świecka w sprawie pokonania kryzysu religijnego 5-13; $\mathrm{S}$. Strękowski - Wolność człowieka $w$ aspekcie moralnym i ascetycznym według Tertuliana. Uwagi literackie 15-22; R. Szmurło - Sprawozdanie z sympozjum patrystycznego. „Chrześcijaństwo na przełomie dziejów”, zorganizowane przez Wydział Nauk Historycznych i Społecznych UKSW $w$ Warszawie dnia 26 X 2000 roku 275-280; (Nr 2) K. Kościelniak - Dynamizm akulturyzacji muzutmańsko-chrześcijańskiej w pierwszych wiekach islamu na Bliskim Wschodzie 5-19.

207. SALESIANUM 63 (2001) nr 1-4:

G. Gatti-Agiografia e teologia morale 97-125; E. Dal Covolo - La catechesi battesimali di san Giovanni Crisostomo 157-167; M. Saeli - Cultura e promozione umana. La cura del corpo e dello spirito dai primi secoli cristiani al medioevo. Contributi e attualizzazioni ulteriori (Troina, 29 ottobre - 1 novembre 1999), 169-182; O. Pasquato - Quale iniziazione per pagani, gnostici e guide? 497-520; M. Marin - L'unita del mondo visibile secondo Plotino (I parte), 613-631.

208. SALMANTICENSIS 48 (2001) nr 1-3:

S. Guijarro - Cristianos en el mundo. Las communidades cristianas de la segunda generación en le sociedad hellenístico-romana 5-39.

209. SALVATORIS MATER 3 (2001) nr 1-4:

(Nr 4) P. Sielużycki - Chrystologia Nestoriusza w rozwoju badań ubiegłego wieku 151-158; J. Królikowski - Wyjątkowość Maryi w mariologii Ojców greckich jako źródło inspiracji ekumenicznych 159-174. 
210. SAPIENZA 54 (2001) nr 1-4:

B. Mondin - L'antropologia cristiana di S. Agostino 3-16.

211. SCIENCE ET ESPRIT 53 (2001) nr 1-3:

G. Madec - Le chant et le temps. Méditation avec Augustin philosophe, théologien et pasteur (Confessiones, livre XI), 111-121; É. Lamirande L'itinéraire religieux de l'impératice Eudocie. Du paganisme à un christianisme éclaté. I: L'étape de Constantinople 309-328; II: L'étape de Jérusalem 475-495.

212. SCOTISH JOURNAL OF THEOLOGY 54 (2001) nr 1-4:

B. Hart - The „, Whole Humanity”: Gregory of Nyssa's Critique of Slavery in Light of His Eschatology 51-69.

213. SCRIPTA THEOLOGICA 33 (2001) nr 1-4:

J.A. Abad Ibáñez - La Trinidad y la Eucaristía 43-70; M. Lluch Baixauli La interpretación del Decálogo en los soglos VII al IX. San Isidoro de Sevilla, Beda el Venerable y los escritores carolingios 71-102; L.F. MatteoSeco - Imitación y sequimiento de Cristo en Gregorio de Nisa 601-622; (Nr 4) Índices ,Scripta Theologica” 23 (1991) - 32 (2000).

214. SÉMIOTIQUE ET BIBLE (2001) nr 101-104:

(Nr 4) A. Fortin - A. Pénicaud - Augustin lecteur des Écritures 3-23.

215. STUDIA ANSELMIANA 132 (2001):

D. Hombergen - The Second Origenist Controversy. A New Perspective of Cyril of Scythopolis' Monastic Biographies as Historical Sources from SixthCentury Origenism 1-448.

216. STUDIA ANTIQUITATIS CHRISTIANAE (2001) nr 15-16:

(Nr 15) H. Pietras - Wprowadzenie 13-17; A. Żurek - Od „paterfamilias” do „Pater noster”. Kontekst kulturowy pojęcia Boga jako „naszego Ojca” w literaturze patrystycznej 18-28; L. Misiarczyk - Bóg Ojciec Justyna Męczennika 29-41; K. Obrycki - Rzymskie pojęcie „paterfamilias” w koncepcji Boga u Tertuliana 42-50; J. Wojtczak - Bóg Ojciec w «Divinae Institutiones» Laktancjusza 51-54; J. Słomka - Bóg Ojciec u Marcelego z Ancyry 55-65; N. Widok - Imiona i tytuty Boga w "Mowach teologicznych» Grzegorza z Nazjanzu 66-74; S. Strękowski - Ojcostwo Boże a skończoność i niedoskonałość ludzka w "Homiliach do modlitwy Ojcze nasz" św. Grzegorza z Nyssy 75-86; J.W. Żelazny - Ojcostwo w «Listach» Teodoreta z Cyru 8795; L. Nieścior - „Filanthropia” Boga i człowieka w świetle pism Nila z Ancyry 96-108; P. Wygralak - Dobroć Boga Ojca w nauczaniu św. Cezarego z Arles 109-116; Propozycje bibliograficzne 117-118; W. Ziemba „Każdemu z nas została dana łaska...” 121-122; B. Częsz - Sens historii wedtug Ojców Kościoła 123-132; A. Żurek - Chrześcijanie a „upadający Rzym" 133-145; L. Misiarczyk - Teologia dziejów w pismach św. Justyna 146-160; J. Słomka - Wspomnienie i oczekiwanie w refleksji eucharystycznej Justyna i Orygenesa 161-168; M. Szram - Czas zbawczej misji Chrystusa 
$w$ świetle duchowego znaczenia licz $b$ w alegorycznej egzegezie aleksandryjskiej 169-176; S. Strękowski - Imperium Rzymskie w koncepcjach historiozoficznych Tertuliana 177-190; W. Myszor - Pax Romana i Pax Christi w wypowiedziach Euzebiusza z Cezarei 191-195; J. Pałucki - Święty Ambroży, opatrznościowy mą̇ Kościoła - między starymi a nowymi czasy 196207; K. Obrycki - Imperium rzymskie w koncepcji dziejów w «Historii przeciw poganom» Orozjusza 208-225; A. Leska - Uwagi o społeczeństwie zachodniego cesarstwa rzymskiego $w$ dobie jego upadku w oparciu o «Historiae adversus paganos» Pawła Orozjusza 226-235; T. Skibiński - Zasady interpretacji Pisma św. w świetle „Praefatio” do "Formulae spiritalis intellegentiae» Eucheriusza z Lyonu 236-255; J. Naumowicz - Wczesnochrześcijańskie obliczenia daty narodzenia Jezusa 256-262; J.W. Żelazny - Czas we wspótczesnej fizyce. Refleksje dotyczące koncepcji czasu i jej wpływ na teologie 263-270; S. Longosz - Hymny św. Hilarego i Kolumby 271-292; A.Z. Zmorzanka - Krótka opowieść o Antychryście Sołowjowa i jej biblijno-patrystyczne tto 293-306; ( $\mathrm{Nr} 16) \mathrm{R}$. Szmurło - Życie monastyczne w pismach Szenutego z Atripe 1-271.

217. STUDIA BOBOLANUM 1 (2001) nr 1-2:

(Nr 2) Apokryficzny żywot świętego Jana Chrzciciela przypisywany świętemu Markowi Ewangeliście (BHG 834, ClAp 181), tłum. R. Zarzeczny 171181.

218. STUDIA GNESNENSIA 15 (2001):

J. Bramorski - Rys historyczny sakramentu pokuty i pojednania 101-117; B. Czyżewski - Niebezpieczeństwa zagrazające kapłanowi w świetle dialogu «O kapłaństwie» św. Jana Chryzostoma 119-132; W. Szukalski - Wolność religijna w nauce Ojców Kościoła 245-262; S. Grzechowiak - Aktualność duchowości benedyktyńskiej - benedyktyńskiego „ora et labora” 417-432.

219. STUDIA HISTORYCZNE 45 (2001) nr 3:

M. Dąbrowska - Zmart Sir Steven Runciman (7 VII 1903 - 1 XI 2000), 180182.

220. STUDIA HISTORYCZNO-TEOLOGICZNE ŚLĄSKA OPOLSKIEGO 21 (2001):

N. Widok - „Physis” w dowodzeniu jedności Trójcy Świętej w nauczaniu Grzegorza z Nazjanzu 233-251.

221. STUDIA LAURENTIANA 1 (2001) nr 1:

D. Kasprzak - Misje w starożytności chrześcijańskiej 27-58.

222. STUDIA LITURGICA 31 (2001) nr 1-2:

A. Stewart-Sykes - Manumission and baptism in Tertullian's Africa: A Search for the Origin of Confirmation 129-149; S. Myers - Initiation by Anointing in Early Syriac-Speaking Christianity 150-170; B. Varghese Some Aspects of West Syrian Liturgical Theology 171-178.

223. STUDIA LOVICIENSIA 3 (2001): 
I. Iuvenalie - La Theotokos e la riconciliazione cosmica secondo i Padri orientali 63-66; Z. Kakacziszwili - Początki państwa gruzińskiego 79-83; tenże - Stosunki persko-gruzińskie 85-89; tenże - Kościót gruziński w pierwszych wiekach 91-97; tenże - Krótki zarys hagiografii gruzińskiej 99-103; J. Krykowski - Spriritus / spiritalis nell'insegnamento penitenziale di Cipriano 145-151; R. Roukema - La tradition apostolique et le canon du Nouveau Testament 211-227.

224. STUDIA MONASTICA 43 (2001) nr 1-2:

A. de Vogüé - Aux origines de l'habit monastique (III $I^{e} I X^{e}$ siècle) 7-20; J. Driscoll - „Love of money” in Evagrius Ponticus 21-30; D. Hombergen - Cyril of Scythopolis and the second origenist controversy 31-46; P. Argá-

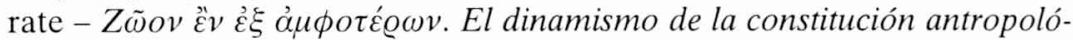
gica en Máximo el Confesor 47-65; A. de Vogüé - La Régle de Saint Benoît

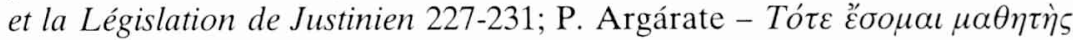

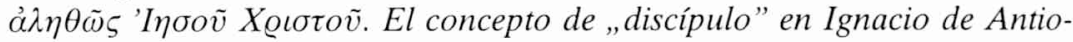
quía 269-296.

225. STUDIA PATRISTICA (2001) t. 34-38:

(Tom 34) K. Bracht - The Question of the Episcopal Seat of Methodius of Olympus Reconsidered 3-10; I.M. Bugár - Zacchaeus and the Veneration of Images: Image of the Emperor - Image of a Saint 11-22; B. Colot - „Pietas”, argument et expression d'un nouveau lien socio-religieux dans le christianisme romain de Lactance 23-32; I.J. Davídson - „Captatio” in the fourthcentury West 33-43; H.A. Drake - Constantinian Echoes in Themistius 4450; J. Willem Drijvers - Marutha of Maipherqat on Helena Augusta, Jerusalem and the Council of Nicaea 51-64; M. Fiedrowicz - Die apologetischen Schriften als "Apologia pro vita sua»: Zur auto-biografischen Komponente einer literarischen Gattung 65-71; G. Greatrex - Justin I and the Arians 7281; K. Greschat - „Woher hast du den Beweis für deine Lehre”? Der altkirchliche Lehrer Rhodon und seine Auseinandersetzung mit den römischen Marcioniten 82-87; O. Hesse - Das altkirchliche Mönchtum und die kaiserliche Politik am Beispiel der Apophthegmen und der Viten des Symeon Stylites und des Daniel Stylites 88-96; R. Klein - Zum pädagogischen Stellenwert der heidnischen Literatur bei den Kirchenvätern des 4. Jahrhunderts 97-110; H. Leppin - Heretical Historiography: Philostorgius 111-124; R. Lizzi Testa - The Bishop, Vir Venerabilis: Fiscal Privileges and Status Definition in Late Antiquity 125-144; B. Lourié - Le second iconoclasme en recherche de la vraie doctrine 145-169; J.E. Merdinger - Bishop Equitius and the Problem of Episcopal Malfeasance in Late Roman Africa 170-176; O. Nicholson - Caelum potius intuemini: Lactantius and a Statue of Constantine 177-196; S. Parvis - Marcellus or Vitalis: who presided at Ancyra 314? 197-203; D. Rankin - Tertullian and the Imperial Cult 204-216; J. Rist Der Mailänder Vereinbarung von 313: Staatsreligion versus Religionsfreiheit 
217-223; H.R. Seeliger - A Collection of Historical Photographs in the Bodleian Library at Oxford and its Significance for Investigations in Roman Catacomb Paintings 224-226; H. Seng - Die Söhne des Synesios 227234; C. Sotinel - Le rôle des expertises dans les débats théologiques du VI siècle 235-249; J. Ulrich - Strafgericht Gottes. Zum Gebrauch der Wörter

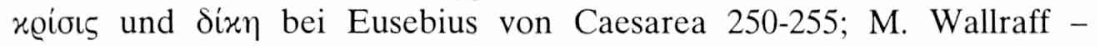
Constantine's Devotion to the Sun after 324, 256-269; W. Wischmeyer A Christian? What's that? On the difficulty of managing Christian diversity in Late Antiquity 270-281; H. Buchinger - Ex. 12, 11. 27. 48 LXX bei Origenes: Textkritik und Antijudaismus 285-293; J.A. Cerrato - Martha and Mary in the Commentaries of Hippolytus 294-297; M. De Groote The New Edition of Oecumenius' Commentary on the Apocalypse 298305; E.A. Dively Lauro - Reconsidering Origen's Two Higher Senses of Scriptural Meaning: Identifying the Psychic and Pneumatic Senses 306317; M. Dulaey - Des roues dans les roues: Ez 1, 15-16 chez les Pères 318-325; R.C. Gregg - Joseph with Potiphar's wife: early Christian commentary seen against the backdrop of Jewish and Muslim interpretations 326-346; R.C. Hill - Theodoret wrestling with Romans (1) 347-352; Two Antiochenes on the Psalms (2) 353-369; A.G. Holder - The Patristic Sources of Bede's Commentary on the Song of Songs 370-375; B. Jeanjean - L'utilisation antihérétique de Ps. 72, 9 par saint Jérôme 376-387; J.F. Kelly - Bede's Use of the Fathers to Interpret the Infancy Narratives 388-394; E. Kessler - The Exegetical Encounter between the Greek Church Fathers and the Palestinian Rabbis 395-412; S.Ch. Kessler - Die patristischen Hoseakommentare: Zur Rezeption der Kleinen Propheten in der Alten Kirche 413-419; E. Kingsmill - Origen's "Commentary on the Song of Songs»: Is there a Hebrew word behind his exposition at 1:2? 420-423; M. Kuyama-Origen and Esther - A Reflection on the „Anti-Jewish” Argument in Early Christian Literature 424-435; D.P. O'Brien - A Comparison between Early Jewish and Early Christian Interpretations of the Jubilee Year 436-442; W.L. Petersen Ephrem Syrus and the Venerable Bede: Do East and West Meet? 443-452; A.M. Ritter - The Fathers as Interpreters of Holy Scripture: Gregory of Nyssa's "De Beatitudinibus» 453-458; M. Starowieyski - Les commentaires bibliques patristiques dans le «De viris illustribus» de S. Jérôme 459-469; K. Stevenson - Animal Rites: The Four Living Creatures in Patristic Exegesis and Liturgy 470-492; D. Stökl - The Biblical Yom Kippur, the Jewish Fast of the Day of Atonement and the Church Fathers 493-502; R.B. Ter Haar Romeny - Biblical Studies in the Church of the East: The Case of Catholicos Timothy I 503-510; J.M. Vercruysse - L'illustration scripturaire dans la Règle VII du "Liber Regularum» de Tyconius 511-517; E. DePalma Digeser - Porphyry, Lactantius, and the Paths to God 521-528; L.G. Patterson - „Pleroma”: The human plenitude, from Irenaeus to Gregory of 
Nyssa 529-540; J.Ch. Salzmann - Per quem omnia facta sunt”: Schriftauslegung zu einem theologischen Satz 541-551; S.J. Shoemaker - Gender at the Virgin's Funeral: Men and Women as Witnesses to the Dormition 552-558; M. Streck - Aristotelische und neuplatonische Elemente in der Anthropologie des Nemesius von Emesa 559-564; T.C.G. Thornton - Jews in Early Christian Eschatological Scenarios 565-571; K.H. Uthemann - Zur Rezeption des «Tomus Leonis» in und nach Chalkedon. Wider den dogmenhistorischen Begriff ,strenger Chalkedonismus” 572-604; (Tom 35) E.M. Atkins - „And immediately he received his sight”: St Macarius and the miracle of the hyena 3-9; D. Bertrand - Force et faiblesse du Noàj chez Évagre le Pontique 10-23; C.M. Chin - Prayer and „Otium” in Cassian's "Institutes» 24-29; J. Chryssavgis - Abba Isaiah of Scetis: Aspects of Spiritual Direction 30-40; G. Clark - Fattening the Soul: Christian asceticism and Porphyry on abstinence 41-51; G. De Nie - Images of the invisible dynamics: self and nonself in sixth-century saints' lives 52-64; B. Degórski - Apunti per una ricostruzione dell'influsso della «Vita S. Pauli Primi Eremitae» sulla «Vita S. Mariae Aegyptiacae» 65-80; G. Gould - The preservation of some authentic material in a Latin collection of "Apophthegmata Patrum» 81-89; S.A. Harvey - On Holy Stench: When the Odor of Sanctity Sickens 90101; N. Henry - A New Insight into the Growth of Ascetic Society in the Fourth Century AD: The Public Consecration of Virgins as a Means of Integration and Promotion of the Female Ascetic Movement 102-109; E. Hisamatsu - Theoria und Energeia bei Gregorius Sinaites 110-113; H. Hunt - „Penthos” and Repentance in St Symeon the New Theologian 114-120; K.W. Noakes - New Epicureans: Some Opponents of Asceticism in the Late Fourth Century 121-124; J.L. North - „, O Mira Mysteria, Quod Non Audiantur Iusti!" (Dem. 23.7): Unanswered Prayer in Aphrahat and Adolf von Harnack 125-131; P. Régerat - Église et prédication dans la «Vita Severini" 132-141; C.T. Schroeder - Purity and Pollution in the Asceticism of Shenute of Atripe 142-147; F.F. Takeda - Monastic Theology of the Syriac Version of the "Life of Antony" 148-157; C. Tornau - Intertextuality in Early Latin Hagiography: Sulpicius Severus and the "Vita Antonii» 158-166; T. Urbainczyk - Cloth and Sackcloth in Theodoret's "Religious History» 167-171; R. Valantasis - Nag Hammadi and Asceticism: Theory and Practice 172-190; M.R. Vivian - Daniel and the Demons: The Battle against Evil as Central to the Authority of the Monk 191-197; M. West - The Law, a Holy School, Serapion of Thmuis and Scripture 198-201; M.J. Edwards - Pauline Platonism: the Myth of Valentinus 205-221; M.J. Edwards - Hebraism, Hellenism and the Gnostic Fall 222-226; N. Förster - Mark the Magician and Valentinian Syncretism 227-233; J.E. Goehring - The Provenance of the Nag Hammadi Codices once more 234-253; P. Bradshaw - A Paschal Root to the Anaphora of the «Apostolic Tradition»? A Response to Enrico Mazza 
257-265; J. Day - Adherence to the „Disciplina Arcani” in the Fourth Century 266-270; A. Gelston - The Biblical Citations in the Syriac Anaphoras of James and the Twelve Apostles 271-274; J.A. Harrill - The Influence of Roman Contract Law on Early Baptismal Formulae (Tertullian, "Ad Martyras» 3), 275-282; A. McGowan - The Inordinate Cup: Issues of Order in Early Eucharistic Drinking 283-291; J. Naumowicz - La date de naissance du Christ d'après Denys le Petit et les auteurs chrétiens antérieurs 292-296; J. Nishiwaki - Eine Sanctus-Formel bei Ambrosius von Mailand: Zur Entwicklungsgeschichte des Sanctus in der Westkirche 297-303; L.M. Peltomaa - The Akathistos Hymn and the Mariology of the Council of Ephesus 304308; G. Rouwhorst - The Origins and Evolution of Early Christian Pentecost 309-322; A. Stewart-Sykes - The Seating of Polycarp in the «Vita Polycarpi»: a liturgy of scholastic Christianity in the third century 323-329; M.A. Tilley - Theologies of Penance during the Donastist Controversy 330337; E. Yarnold - The Body-Soul Relationship mainly in connection with Sacramental Causality 338-342; M. Albert - À propos des citations scripturaires de la correspondence de Jacques de Saroug 345-352; P. Allen - Severus of Antioch as Pastoral Carer 353-368; R.A. Arthur - A Sixth-Century Origenist: Stephen bar Sudhaili and his Relationship with Ps-Dionysius 369373; J.W. Childers - The Georgian «Life of Porphyry of Gaza» 374-384; B. Fitch Fairaday - Isaac of Nineveh's Biblical Typology of the Cross 385390; M. Greatrex - Jacob of Edessa's use of Theophrastus - «De Lapidibus» 391-394; S.H. Griffith - The Thorn among the Tares: Mani and Manichaeism in the Works of St Ephraem the Syrian 395-427; T. Koonammakkal - Ephrem's Polemics on the Human Body 428-432; E. Lash - Metrical Texts of Greek Ephrem 433-448; C. Leonhard - Ǐšo'dād's Commentary on Psalm 141, 2: A Quotation from Theodore of Mopsuestia's Lost Commentary 449457; K.E. McVey - Ephrem the Syrian's theology of divine indwelling and Aelia Pulcheria Augusta 458-465; L. Mirri - La preghiera nella "Vita Sanctae Mariae Aegyptiacae» 466-483; M. Papoutsakis - „A small thing”: Early Syriac Views of Zoar (Gen. 19:20-23) 484-487; R. Roux - The Concept of Orthodoxy in the "Cathedral Homilies" of Severus of Antioch 488-493; A. Shemunkasho - The Healing of Interior and Exterior Blindness in Ephrem 494-501; C. Shepardson - Anti-Jewish Rhetoric and Intra-Christian Conflict in the Sermons of Ephrem Syrus 502-507; D.G.K. Taylor - The Christology of the Syriac Psalm Commentary (AD 541/2) of Daniel of Salah and the „Phantasiast” Controversy 508-515; D.W. Winkler - Die Christologie des ostsyrischen Katholikos Sh'yahb III. von Adiabene (580-659), 516526; W. Witakowski - Ethiopic and Hebrew versions of the legend of «The Finding of the Holy Cross» 527-535; (Tom 36) F. Clark - The unmasking of the pseudo-Gregorian "Commentary on Kings» and its relevance to the study of Benedictine origins 3-8; M.G. Guérard - Le contenu de l' Épitomé» de 
Procope sur le Cantique 9-22; J.T. Lienhard - Augustine against Maximinus: Towards a Critical Edition 23-27; T.W. Mackay-Apocalypse Comments by Primasius, Bede, and Alcuin: Interrelationship, Dependency, and Individuality 28-34; P. Mattei - Remarques sur la tradition textuelle (manuscrite et imprimée) $d u$ "De rebaptismate» 35-45; B. Neil - The Greek "Life of Maximus the Confessor» (BHG 1234) and its Three Recensions 46-53; P. Parvis - The Textual Tradition of Justin's «Apologies»: A Modest Proposal 54-60; K. Pollmann - The Transformation of the Epic Genre in Christian Late Antiquity 61-75; B. Pouderon - Aristide et les Juifs. À propos d' "Apol.» 14, 2 Ba 76-86; N. Sakwarelidse - Zur Übertragung einiger christologischer Termini in den altgeorgischen Übersetzungen Maximos des Bekenners 8793; P. Sellew - The Hundredfold Reward for Martyrs and Ascetics: Ps.-Cyprian, "De centesima, sexagesima, tricesima» 94-98; J. Ulrich - Straf-

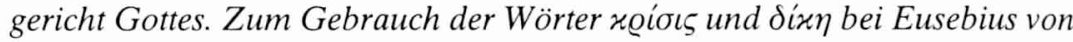
Caesarea 99-104; F. Young - The "Apostolic Constitutions»: a methodological case-study 105-115; M. Harrington - Anastasius the Librarian's Reading of the Greek Scholia on the Pseudo-Dionysian Corpus 119-125; B. Judic - Lire Grégoire le Grand à Saint-Martial de Limoges 126-133; L. Khoperia Maximus the Confessor in ancient Georgian sources 134-139; M. MargoniKögler - Typologie in den christlichen Vergilcentonen 140-152; O.M. Bakke - The Rhetorical Composition of the First Letter of Clement 155-162; J. Behr - Irenaeus on the Word of God 163-167; F. Bergamelli - Dal Padre al Padre. Il Padre come principio e termine del Cristo e del cristiano in Ignazio di Antiochia 168-176; S.P. Bergjan - How to speak about early Christian apologetic literature? Comments on the recent debate 177-183; D.J. Bingham - Knowledge and Love in Irenaeus of Lyons 184-199; E. De Bhaldraithe - The Christology of Ignatius of Antioch 200-206; B. Garstad - Theophilus of Antioch, Pseudo-Justin, and Thallus' Treatment of Moses 207-209; S.L. Graham - Structure and Purpose of Irenaeus" «Epideixis» 210-221; B.M. Guevin - The Natural Law in Irenaeus of Lyons" "Adversus Haereses»: A Metaphysical or a Soteriological Reality? 222-225; C.E. Hill - Ignatius and the Apostolate: The Witness of Ignatius to the Emergence of Christian Scripture 226-248; T.J. Horner - Listening to Trypho: Uncovering the Subtext of Justin's "Dialogue» 249-255; A.Chr.L. Jacobsen - The Philosophical Argument in the Teaching of Irenaeus on the Resurrection of the Flesh 256-261; C.N. Jefford - Conflict at Antioch: Ignatius and the "Didache" at Odds 262-269; E. Osborn - Irenaeus and Xenophanes Argument and Parody 270-281; G. Pani - Il concetto di piekeia nella struttura della "Prima Clementis» 282-292; W. Rordorf - La «Didachè» en 1999 293-299; A. Rudolph - Die Judenchristen in Justins Dialog mit Tryphon 300-306; J.A. Trumbower - «Apocalypse of Peter» 14, 1-4 in relation to Confessors' Intercessions for the Non-Christian Dead 307-312; P. Widdicombe - 
Justin Martyr's Apophaticism 313-319; A. Brent - Cyprian and the question of „ordinatio per confessionem” 323-337; J.P. Burns - Confessing the Church: Cyprian on Penance 338-348; G.D. Dunn - The Ancestry of Jesus according to Tertullian: „ex David per Mariam” 349-355; C. Lange - Das Christentum als ,, secta”? Ein Vorschlag zur Lesung von Minucius Felix 4,4 356-363; O. Nicholson - Broadening the Roman Mind: Foreign Prophets in the Apologetic of Lactantius 364-374; W. Tabbernee - To Pardon or not to Pardon? North African Montanism and the Forgiveness of Sins 375-386; K.J. Torjesen - The Episcopacy - Sacerdotal or Monarchical? The Appeal to Old Testament Institutions by Cyprian and the «Didascalia» 387-406; L. Emmett - Clement of Alexandria's "Protrepticus» and Dio Chrysostom's "Alexandrian Oration» 409-414; M. Fédou - L'unicité du Christ selon le "Contre Celse» d'Origène 415-420; R.E. Heine - The Prologues of Origen's Pauline Commentaries and the "Schemata Isagogica" of Ancient Commentary Literature 421-439; A.E. Johnson - Allegorical Narrative and Evangelism: „Three Day's Journey” in Origen's Homilies on Exodus 440-444; U. Neymeyr - Der Protreptikos des Clemens und des Galen 445-448; K. Parel - The Disease of the Passions in Clement of Alexandria 449-455; T. Weinandy - Origen and the Suffering of God 456-460; K. Anatolios - The Influence of Irenaeus on Athanasius 463-476; W.H.K. Boulos - St Athanasius' Doctrine of Grace in "Contra Arianos» I, 477-481; D. Brakke - Athanasius" "Epistula ad Epiphanium» and Liturgical Reform in Alexandria 482-488; A. Canellis - Arius et les „Ariens” vus par les Lucifériens dans le "Libellus Precum» de Faustin et Marcellin 489-501; J.D. Ernest - Athanasian Scripture Citations 502-508; D. Gonnet - The Salutary Action of the Holy Spirit as Proof of His Divinity in Athanasius" "Letters to Serapion" 509-513; J.D. Smith III - Reflections on Euzoius in Alexandria and Antioch 514-519; (Tom 37) C. Apostolopoulos - AOPISTON. Anmerkungen zur Vorstellung vom Unbestimmten - Unendlichen der "göttlichen Natur" bei Gregor von Nyssa 3-11; M.R. Barnes - „The Burden of Marriage” and Other Notes on Gregory of Nyssa's "On Virginity» 12-19; T. Böhm - Basil of Caesarea, "Adversus Eunomium» I-III and Ps. Basil, "Adversus Eunomium»IV-V, 20-26; S.K. Burns - Cappadocian Encratism and the Macarian Community 27-32; F. Cardman - Whose Life Is It? The "Vita Macrinae» of Gregory of Nyssa 33-50; K. Corrigan - The problem of personal and human identity in Plotinus and Gregory of Nyssa 51-68; S. Elm - Orthodoxy and the True Philosophical Life: Julian and Gregory of Nazianzus 69-85; W.E. Helleman - Cappadocian Macrina as Lady Wisdom 86-102; S.R. Holman - Taxing Nazianzus: Gregory and the Other Julian 103-109; A.G. Keidel "Hesychia", Prayer and Transformation in Basil of Caesarea 110-120; E. Kiria - "De Oratione Dominica» of Gregory of Nyssa and Its Old Georgian Translation 121-125; M. Laird - Apophasis and Logophasis in 
Gregory of Nyssa's "Commentarius in Canticum canticorum» 126-132; A. Lallemand - L'ivresse chez Basile et Grégoire de Nysse 133-139; J. Leemans - A Preacher-Audience Oriented Analysis of Gregory of Nyssa's Homily on Theodore the Recruit 140-146; N.A. Lipatov - "The Statement of Faith” Attributed to St. Basil the Great 147-159; J.A. McGuckin - Autobiography as Apologia in St. Gregory of Nazianzus 160-177; N. McLynn - Gregory Nazianzen's Basil: The Literary Construction of a Christian Friendship 178193; A. Meis - El Ocultamiento de Dios en los «Comentarios al Cantar de los Cantares" de Gregorio de Nisa y Pseudo-Dionysio Areopagita 194-206; H.A.M. Mooney - The Notion of the Liberality of God in Gregory of Nyssa and Johannes Scottus Eriugena 207-211; A.A. Mosshammer - Gregory of Nyssa as Homilist 212-239; A. Muraviev - The Syriac Julian Romance as a Source the Life of St. Basil the Great 240-249; A. Redovičs - Gregory of Nazianzus (Or. 29.2) in Maximus the Confessor's «Ambigua» 250-256; J. Reynard - L'antijudaïme de Grégoire de Nysse et du pseudo-Grégoire de Nysse 257-276; D.G. Robertson - Relatives in Basil of Caesarea 277-287; K. Rombs - Gregory of Nyssa's Doctrine of „Epektasis”: Some Logical Implications 288-293; J.C. Skedros - The Cappadocian Fathers on the Veneration of Martyrs 294-300; D. Woods - Dating Basil of Caesarea's Correspondence with Arintheus and his Widow 301-307; H. Amirav - Exegetical Models and Chrysostomian Homiletics: The Example of Gen. 6, 2, 311-318; G. Bady - La méthode exégétique du Commentaire inédit sur les Proverbes attribué à Jean Chrysostome 319-327; T.D. Barnes - The Funerary Speech for John Chrysostom $\left(B H G^{3} 871=C P G\right.$ 6517), 328-345; D. Bathrellos The Relationship between the Divine Will and the Human Will of Jesus Christ according to Saint Maximus the Confessor 346-352; P. BlaudeauLe cas Pierre Monge au regard des sources monophysites d'origine palestinienne (Fin V $V^{e}$ s. - Début VI $I^{e}$ s.), 353-360; P.M. Blowers - The Passion of Jesus Christ in Maximus the Confessor: A Reconsideration 361-377; M.O. Boulnois - Liberté et théodicée selon Cyrille d'Alexandrie 378-388; P.C. Bouteneff - Placing the Christology of Didymus the Blind 389-395; C. Broc - La femme de Job dans la prédication de Jean Chrysostome 396403; P. Bruns - Polychronius von Apamea' Der Exeget und Theologe 404412; J.D. Cassel - Key Principles in Cyril of Alexandria's Exegesis 413-420; Y. De Andia - Symbole et mystère selon Denys l'Aréopagite 421-451; A. Doval - Cyril of Jerusalem's Theology of Salvation 452-461; L. Dysinger The „Logoi” of Providence and Judgement in the Exegetical Writings of Evagrius Ponticus 462-471; J. Getcha - The Unity of the Mystery of Salvation according to the Festal Homilies of Hesychius of Jerusalem 472-476; M. Ghattas - Der Idee von der „,hypostatischen Union” bei Didymos dem Blinden von Alexandria in den Schriften von Tura 477-481; A. Golitzin Revisiting the „Sudden”: Epistle III in the "Corpus Dionysiacum» 482-491; 
T. Graumann - Väterzitate bei Theodoret 492-498; T. Grdzelidze - Liturgical Space in the Writings of Maximus the Confessor 499-504; T. Hainthaler „Anders konnte der Mensch nicht gerettet werden”: Anastatius von Antiochien und seine Christologie nach "Or.» III, 505-513; W. Harmless - „Salt for the Impure, Light for the Pure": Reflections on the Pedagogy of Evagrius Ponticus 514-526; A. Hartney - Men, Women and Money - John Chrysostom and the Transformation of the City 527-534; R. Hennings - Eusebius von Emesa: zwei Osterpredigten gegen die Juden 535-542; D. Keating - The Twofold Manner of Divine Indwelling in Cyril of Alexandria: Redressing an Imbalance 543-549; A.H.B. Logan - Marcellus of Ancyra, defender of the faith against heretics and pagans 550-564; J. Marsaux - Pour une nouvelle approche de l'eucharistie chez Jean Chrysostome à partir de la pragmatique 565-570; K. McCarthy Spoerl - Apollinarius on the Holy Spirit 571-592; M. Plested - The Christology of Macarius-Symeon 593-596; M.B. Simmons - Eusebius' Panegyric at the Dedication of the Church at Tyre A.D. 315: Anti-Porphyrian Themes in Christian Rhetoric of the Later Roman Empire 597-607; L. Thunberg - Spirit, Grace and Human Receptivity in St. Maximus the Confessor 608-617; T. Tollefsen - Did St. Maximus the Confessor have a Concept of Participation? 618-625; J. Van Rossum - Gregory of Cyprus and Palamism 626-630; J.P. Williams - The Incarnational Apophasis of Maximus the Confessor 631-635; (Tom 38) J.S. Alexander - Criteria for Discerning Donatist Sermons 3-7; I. Buchet - Honoratus: le destinataire de la "Lettre» 140 est-il l'ancien ami manichéen d'Augustin? 8-15; A.I. Bouton-Touboulic - L'esthétique de l'ordre chez saint Augustin: les images du discours et du tableau 16-24; J. Brachtendorf - The Decline of Dialectic in Augustine's Early Dialogues 25-30; P.C. Burns - Roles of Roman rhetorical „exempla” in Augustine's "City of God» 31-40; A.M.C. Casiday - Cassian, Augustine, and "De Incarnatione» 41-47; F.G. Clancy - Augustine's Sermons for the Dedication of a Church 48-55; J. K. Coyle - Revisiting the Adversary in Augustine's "Contra adversarium legis et prophetarum» 5663; R. Dobbins - Silence and Speech in the Ostia Experience: The Case of "fons vitae" 64-69; R. Dodaro - The Theologian as Grammarian: Literary Decorum in Augustine's Defense of Orthodox Discourse 70-83; D.E. Doyle - Doctrinal Discipline in the Letters of St. Augustine 84-94; Y.M. Duval Pélage en son temps: Données chronologiques nouvelles pour une présentation nouvelle 95-118; P. Fredriksen - Augustine and Israel: "Interpretatio ad litteram", Jews, and Judaism in Augustine's Theology of History 119-135; T. Fuhrer - Zu Form und Funktion von Augustins exegetischen Schriften 136-152; P. Gemeinhardt - „Geboren aus dem Wesen des Vaters ...”. Das Glaubensbekenntnis von Nizäa und Augustins neunizänische Theologie 153-168; W.A. Hannam - „Ad illud ubi permanendum est”: The Metaphysics of St Augustine's , usus-fruitio” Distinction in relation to Love of Neigh- 
bour, «De Doctrina christiana» I, 169-173; G. Heidl - „, Ordinatissimum Dei Munus". The Trinity in Augustine's "De Fide et Symbolo» 2, 2, 174-180; E. Hill - A Possible Debt of Augustine's to Tychonius: The „male” contemplative and ,female" active functions of the human mind: "De Trinitate» XII 181-183; M. Jackson - Miracles and „Spiritual Correctness” in the Theology of St. Augustine 184-189; G. Kendeffy - Démarches néo-académiciennes chez saint Augustin après le "Contra Academicos» 190-198; J.P. Kenney Saint Augustine and the Limits of Contemplation 199-218; W.E. KlingshirnThe figure of Albicerius the diviner in Augustine's "Contra Academicos» 219-223; S. Mratschek - „Te velimus... consilii participem”: Augustine of Hippo and Olympius - a case study of religious-political cooperation in the fifth century 224-232; H. Müller - Theory and Practice of Preaching: Augustine, "De doctrina christiana» and "Enarrationes in psalmos» 233-237; J.M. Norris - Abyss: Cosmic Darkness and Spiritual Depravity in the "Confessions 238-244; E. Rebillard - Augustin et ses autorités: l'élaboration de l'argument patristique au cours de la controverse pélagienne 245-263; J. Ries - Le jugement porté sur le Manichéisme par saint Augustin à la lumière de son expérience relatée dans les «Confessions" 264-274; R. Rombs - Saint Augustine on the Origin of Souls: The Logic of Robert J. O'Connell 275-282; T.A. Smith - Agonism and Antagonism: Metaphor and the Gallic Resistance to Augustine 283-289; N. Strand - Augustine on Predestination and Divine Simplicity: The Problem of Compatibility 290-305; J. TorchiaThe Significance of the „communicatio idiomatum” in St. Augustine's Christology, with special reference to his rebuttal of later Arianism 306-323; J. Van Amersfoort - Some Remarks on the Gospel Tradition in the Anti-Manichean Writings of Augustine of Hippo 324-330; M.A. Vannier - L'Apport $d u$ «Sermon Dolbeau 26» 331-337; O. Velasquez - From „Dubitatio” to „Securitas”: Augustine's "Confessions» in the context of uncertainty 338341; R.E. Winn - The Moral and Intellectual Failure of Divine Inspiration in Augustine's "De Ordine» 342-347; D.F. Wright - „Non posse peccare” in this life? St. Augustine, "De correptione et gratia» 12:33 348-353; T.D. Barnes - A Neglected Letter of Ambrose 357-361; S.J.B. Barnish - Sacred Texts of the Secular: Writing, Hearing, and Reading Cassiodorus" "Variae» 362-370; E. Cavalcanti - The Sermon of Leo the First on the Transfiguration (Serm. LI Chavasse) 371-376; F. Cocchini - Gregorio Magno e la dottrina della ,triarchia petrina” 377-384; I.J. Davidson - Social Construction and the Rhetoric of Ecclesial Presence: Ambrose's Milan 385-393; T.S. Ferguson - Golden Bough, Golden Tongue, Golden Jewel: "Aeneid» 6 in the "Expositio Virgilianae Continentiae» of Fulgentius 394-399; D.M. Foley Ambrose's Adaptation of Medical Knowledge 400-404; U. Heil - Die Korrespondenz des Avitus von Vienne 405-409; E.D. Hunt - The Date of the "Itinerarium Egeriae» 410-416; A.S. Jacobs - The Place of the Biblical Jew 
in the Early Christian Holy Land 417-422; D. Lambert - The Pseudonymity of Salvian's "Timotheus ad Ecclesiam» 423-428; U.M. Lang - Christological Themes in Rusticus Diaconus" "Contra Acephalos Disputatio" 429-434; M. Milhau - Hilaire de Poitiers, "De Trinitate», 2, 1: Formule baptismale et foi trinitaire 435-448; S. Müller-Abels - ,Scio enim quod redemptor meus vivat" - Auferstehung bei Gregor dem Großen ("Moralia in Iob XIV», 67-78) 449-459; K.E. Power - The Sword of the Word: An Aspect of Mystical Marriage in Ambrose of Milan 460-466; D. Ramos-Lissón - Le binôme liberté - virginité dans les écrits exhortatifs de saint Ambroise sur la virginité 467-474; L.M. Sullivan - Bursting the Bonds of Night: Images of the Apocalypse in Prudentius" "Cathemerinon» 475-480; J.H.A. Van Banning Gregory the Great and the surviving Arianism of his time: Did he know the "Opus Imperfectum in Matthaeum»? 481-495; J. Voelker - Marius Victorinus' Exegetical Arguments for Nicene Definition in "Adversus Arium» 496-502; D. Weber - Klassische Literatur im Dienst theologischer Polemik: Julian von Eclanum, "Ad Florum» 503-509; M. Zelzer - Das ambrosianische Corpus «De virginitate» und seine Rezeption im Mittelalter 510-523.

226. STUDIA PŁOCKIE 29 (2001):

W. Turek - Prymat biskupa Rzymu w okresie patrystycznym. Rozwój idei od Klemensa Rzymskiego do Leona Wielkiego 51-58; D. Majewski - Podróż papieża Wigiliusza do Konstantynopola $w$ latach 545-547, 255-262.

227. STUDIA THEOLOGICA 55 (2001) nr 1-2:

B.A. Pearson - Early Christianity and Gnosticism in the History of Religions 81-106.

228. STUDIA THEOLOGICA VARSAVIENSIA 39 (2001) nr 1-2:

W. Dąbrowski - Myśl chrystologiczna w «Super Boetium De Trinitate» św. Tomasza z Akwinu 63-86; R. Szmurło - Polemika z manicheizmem w pismach Szenutego z Atripe 195-202.

229. STUDIA WARMIŃSKIE 37 (2000) nr 1-2:

A. Zellma - Relacje zachodzace między katecheza a liturgia w czasach katechumenatu wczesnochrześcijańskiego 597-603.

230. STUDIA WŁOCŁAWSKIE 4 (2001):

T. Kaczmarek - Chrystus i męczennik wedtug świadectw patrystycznych z trzech pierwszych wieków 144-153; Z. Wróbel - Od św. Augustyna do św. Grzegorza z Tours. O wstawiennictwie świętych 313-322.

231. ST. VLADIMIR'S THEOLOGICAL QUARTERLY 45 (2001) nr 1-4: C.R. Hutcheon - „A Sacrifice of Praise”: A Theological Analysis of the PreSanctus of the Byzantine Anaphora of St. Basil 3-23; W.S. Royer - The Ancient of Days. Patristic and Modern Views of Daniel 7, 9-14, 137-162; R.C. Hill - St. John Chrysostom's "Homilies on Hannah» 319-338; S. Alexopoulos - An Example of Ecclesial Reconciliation in the Early Church: 
Three Homilies by Paul of Emesa and Cyril of Alexandria 339-358; A.M. Casiday - „Apatheia” and Sexuality in the Thought of Augustine and Cassian 359-394; T.T. Tollefsen - The Ethical Consequences of the Christian Conception of Nature as Created by God 395-408.

232. STUDIES IN SPIRITUALITY 11 (2001):

C. Connors-Nelson - The Way of Perfection in the "Acts of Thomas" 144-165.

233. ŚLĄSKIE STUDIA HISTORYCZNO-TEOLOGICZNE 34 (2001):

W. Myszor - Wybór biskupa w świetle "Listów» św. Cypriana 109-114; S. Pisarek - Czy św. Paweł zrealizowat projekt odbycia podróży apostolskiej na krańce Zachodu, to jest do Hiszpanii (Rz 15, 24. 8), 115-143.

234. TEOLOGÍA 38 (2000) nr 75-76:

(Nr 76) M.A. Brusco - Vida y concimiento de Dios en san Gregorio de Nisa 47-63.

235. TEOLOGIA 26 (2001) nr 2:

E. Bolis - Storia e storie della spiritualità. Modi teorici e prospettive di ricerca 213-137.

236. TEOLOGIA Y VIDA 42 (2001) nr 1-3:

S. Fernández - La salvación sin mediaciones según Marción y la respuesta de Tertuliano 50-73; C. Pierantoni - Las mediaciones de la salvación en San Agustín 151-171; D. Ramos-Lissón - En torno a la exégesis de San Gregorio Magno sobre el "Cantar de los Cantares» 241-265.

237. TEOLOGICKÉ TEXTY 12 (2001) nr 1-4:

C.V. Pospísil - Christologie velkých koncil patristické epochy 134-135

238. TERMINUS 3 (2001) z. 1-2:

M. Bielawski - Giovanni Cassiano e Paolo Apostolo - tra esegesi e spiritualità 71-116.

239. THEOFORUM 32 (20001) nr 1-2:

Ph.L. Tite - The Holy Spirit's Role in Origen's Trinitarian System. A Comparaison with Valentinian Penumatology 131-164; K.C. Russel - St. Columban's Monastic Lectures 165-180.

240. ӨЕОАОГІА 72 (2001) nr 1-2:

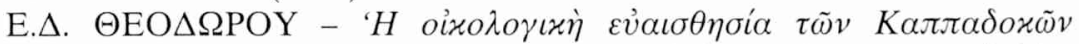

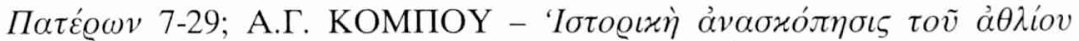

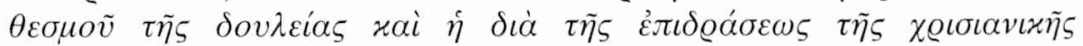

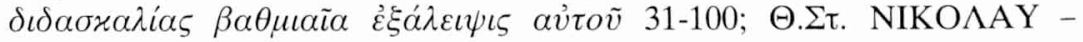

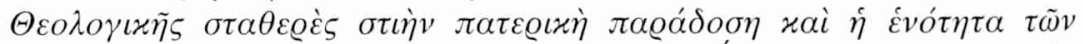

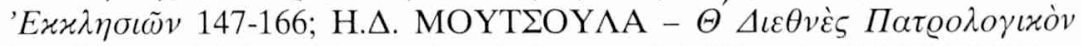

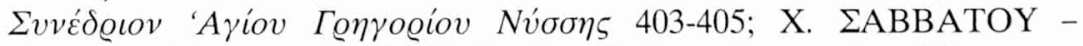

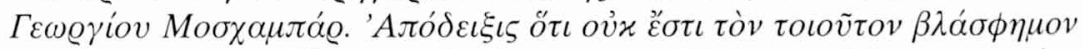

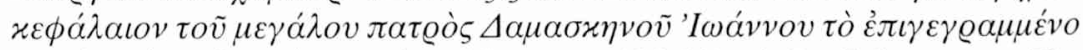

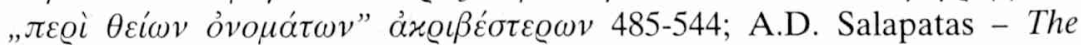


liturgical role of the Deaconess in the "Apostolic Constitutions» 559-578;

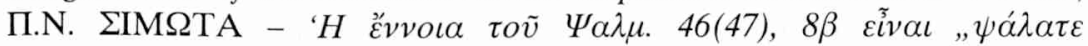

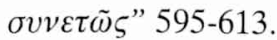

241. THEOLOGICAL STUDIES 62 (2001) nr 1-4:

M.A. Tilley - The Collapse of a Collegial Church: North African Christianity on the Eve of Islam 3-22; G.D. Dunn - Divine Impassibility and Christology in the Christmas Homilies of Leo the Great 71-85; M.F. Connel Descensus Christi ad Infernos - Christ's Descent to the Dead 262-282; W. Harmless - R.R. Fitzgerald - The Sapphire Light of the Mind: The "Skemmata» of Evagrius Ponticus 498-529.

242. THEOLOGICA THORUNIENSIA (2001) nr 1-2:

(Nr 2) F. Drączkowski - Uniwersalny wymiar kerygmatu wczesnochrześcijańskiego 5-21.

243. THEOLOGIE UND GLAUBE 91 (2001) nr 1-4:

S. Haas - Aporetischer, als Augustinus zugeben würde. Paul Ricoeurs Interpretation der Zeit-Abhandlung aus dem elften Buch der «Confessiones» 4358; A. Viciano - Die ambivalente Bedeutung der Kirchenväter für die moderne Theologie 59-68; J. Ernesti - „Der Natur der Sache nach kann es nur wenige Priester geben". Historische Überlegungen zur Wahrnehmung des Priestermangels 462-477.

244. THEOLOGIE UND PHILOSOPHIE 76 (2001) nr 1-4:

J. Dietrich - Negative Theologie bei Pseudo-Dionysius Areopagita und Mose ben Maimon 161-184; P. Gemeinhardt - Die Trinitätslehre des Michael Psellos. Griechischer Neunizänismus als philosphische Theologie im 11. Jahrhundert 509-529.

245. THEOLOGISCHE QUARTALSCHRIFT 181 (2001) nr 1-4:

H.J. Vogt - Sind die Ignatius-Briefe antimarkionitisch beeinflußt? 1-19.

246. THEOLOGISCHE ZEITSCHRIFT 57 (2001) nr 1-4:

P. Höffken - Bekehrung von Nichtjuden als (Nicht-) Thema bei Josephus Flavius 391-406.

247. THEOLOGY TODAY 58 (2001) nr 1-4:

S.S. Fotiou - Reconsidering Monasticism: Blood and Spirit 509-516.

248. THEOTOKOS 9 (2001) $\mathrm{nr} 1-2$ :

V. Mazzucco - La donna e il cristianesimo nei primi tre secoli 29-59;

E. Giannarelli - Maria fra teologia, spiritualità e vita quotidiana: il difficile emergere di un modello nei secoli I-III, 61-82; A. Gila - La Vergine Madre e l'Antico Testamento secondo i primi Padri della Chiesa 83-128; L. Gambero - Maria ,vergine” e „madre” nell'esegesi patristica del NT nei primi tre secoli 129-151; C. Corsato - La tipologia „Eva-Chiesa - Maria” nella tradizione patristica prenicena 153-190; E. Norelli - Maria nella letteratura apocrifa dei primi tre secoli 191-225; F. Bergamelli - La verginità di Maria nelle «Lettere» di Ignazio di Antiochia 311-327; L. Langella - Il Vangelo di Maria in 
Giustino martire 329-352; C. Corsato - Accenni mariani in Melitone di Sardi 353-357; F. Rodrigo Polanco - La mariologia di Sant'Ireneo 359-400; E. Peretto - Riferimenti mariani negli ebioniti e nei doceti 401-453; U. Utro - L'immagine di Maria nell'arte delle origini. Dalle prime raffigurazioni al Concilio di Nicea (325), 455-480.

249. THOMIST 65 (2001) nr 1-4:

R. Cross - A Recent Contribution on the Distinction between Monophysitism and Chalcedonianism 361-383.

250. VETERA CHRISTIANORUM 38 (2001) nr 1-2:

M. del Verme - «Didaché» e origini cristiane. Una bibliografia per lo studio della «Didaché» nel contesto del giudaismo cristiano 5-39, 223-245; P. de Santis - La terminologia relativa ai luoghi di culto nel "Liber Pontificalis». Da Pietro a Pelagio II 41-83; M. Simonetti - Origene e le moltiplicazioni dei pani 85-101; F. Tiddia - Terminologia della luce e battesimo nelle iscrizioni greche cristiane 103-124; L. Viscido - Una note sulle reliquie del martire Acacio 125-130; G. Otranto - In ricordo di Antonio Quacquqrelli 217221; A.E. Felle - I reperti epigrafici del complesso do S. Ilario „ad bivium" presso Valmontone (Roma) 247-285; M. Gagliardi - Un'ipotesi su "Adversus haereses» III 22, 4, 287-292; M. Girardi - L'uomo imagine somigliante di Dio (Gen 1, 26-27) nell esegesi dei Cappadoci 293-314; $\mathrm{G}$. Otranto - La diffusione del cristianesimo e l'organizzazione ecclesiastica della Marsica fino all'Altomedioevo 315-330; G. Nigro - Su alcuni recenti manuali di Storia della Chiesa antica 331-336; A. Capone - I classici nella cultura dei secoli IV-VIII (Monte Sant'Angelo 1-5 ottobre 2001), 337-340. 251. VIGILIAE CHRISTIANAE 55 (2001) nr 1-4:

I. Perrone - Prayer in Origen's "Contra Celsum»: The Knowledge of God and the Truth of Christianity 1-19; N.F. Denzey - Genesis Traditions in Conflict?: The Use of Some Exegetical Traditions in the „Trimorphic Protonnoia" and the Johannine Prologue 20-44; H. Schneider - Thekla und die Robben 45-57; W. Mayer - Patronage, Pastoral Care and the Role of the Bishop at Antioch 58-70; Th. Gärtner - Zur christlichen Imitationstechnik in der Vita Sancti Martini des Paulinus von Petricordia 71-85; A. Dearn - The «Passio S. Typasii Veterani» as a Catholic Construction of the Past 86-98; A. Alcock - The Sale of Mani 99-100; A. Kotzé - Reading Psalm 4 to the Manicheans 119-136; Th.F. Martin - „Psalmus Gratiae Dei: Augustine's Reading of Psalm 31, 137-155; A. Piras - Fulgentius von Ruspe, "Epist.» I 3, 3: "Thapsensis” oder „Tharrensis”? 156-160; A.G. Cooper - Maximus the Confessor on the Structural Dynamics of Revelation 161-186; Y.N. Youssef - Un complement de l'Asceticon Copte de l'Abbé Isaïe 187-190; M. de Groote - Die Kirchenväter in Oecumenius" "Scholia in Johannem Chrysostomum»191-200; D. Woods - The Church of St. Acacius at Constantinople 201-207; V. Buchheit - Patristischer Hintergrund im 12. Geistli- 
chen Lied des Novalis 208-214; A.D. DeConick - The True Mysteries. Sacramentalism in the Gospel of Philip 225-261; N.I. Frederikson - L'esprit saint et les esprits mauvais dans le Pasteur d'Hermas: sources et prolongements 262-280; A. Orlov - A. Golitzin - „Many Lamps are Lightened from the One": Paradigms of the Transformational Vision in Macarian Homilies 281-298; F.B.A. Asiedu - The Song of Songs and the Ascent of the Soul: Ambrose, Augustine, and the Language of Mysticism 299-317; T. Nicklas Erzähler und Charakter zugleich. Zur literarischen Funktion des „Petrus” in dem nach ihm benannten Evangelienfragment 318-326; J. Holzhausen Irenäus und die Valentinianische Schule. Zur "Praefatio" von "Adv. Haer.» I, 311-355; Th.C.K. Ferguson - The Rule of Truth and Irenaean Rhetoric in Book I of "Against Heresies» 356-375; P. Schüngel - Die Valentinreferat des Irenäus von Lyon "Haer.» I 11, 1, 376-405; A. Meis - Die Theologische Bedeutung des mocrnwj zu "Adversus Arium et Sabellium" von [Gregor von Nyssa] 406-426; E. Lucchesi - La Légende d'Eudoxie et du Saint Sépulcre dans un Papyrus Copte de Berlin 427-429.

252. VITA MONASTICA 55 (2001) nr 216-219:

(Nr 219) A. Catella - La „Cinquantina” pasquale 5-34

253. VIVENS HOMO 12 (2001) nr 1-2:

I. Rupnik - Tradizione orientale e tradizione occidentale dell'imagine 137-148; C. Nardi - Musica e liturgia nella riflessione dei Padri della Chiesa 169-181; C. Nardi - Reliquie tra culto e superstizione. Significato di una devozione nella letteratura patristica 359-378.

254. VOX LATINA 36 (2000) nr 139-142:

H.L. Barth - S. Augustini vitae operisque breve summarium 191-205; G. Pérez I Dura - Iohannis Ludovici Vivis ad divi Aurelii Augustini «De civitate Dei» libros commentariorum genesis 310-320; Aurelius Augustinus - Homilia natalicia (Sermo 189 - PG 38, 1005-1007), 470-471.

255. W DRODZE (2001) nr 1-12:

(Nr 12) Św. Efrem - Hymn o narodzeniu Pańskim (SCh 459), tłum. Hanna M. Komornicka 100-104.

256. WARSZAWSKIE STUDIA TEOLOGICZNE (2000) nr 13 i (2001) nr 14: (Nr 13) J. Naumowicz - Wcielenie Boga i zbawienie człowieka. Złota reguła soteriologii patrystycznej 17-30; Trzy apokryfy syryjskie, przekład, wstęp i komentarz W. Witakowski 119-133; M. Janocha - Ofiarowanie Maryi w ukraińskim malarstwie ikonowym 135-154; (Nr 14) Proklus z Konstantynopola - Homilia o obrzezaniu Pańskim (Homilia 22: De circumcisione Domini, CPG 5821), przekład, wstęp i przypisy R. Zarzeczny 78-80; J. Krykowski - Il richiamo alla conversione negli scritti di Tertulliano 8196; T. Stępień - Filozoficzne podstawy rozumienia Opatrzności u greckich Ojców Kościoła 97-114; M. Starowieyski - Autobiografia i elementy autobiograficzne w literaturze wczesnochrześcijańskiej 115-130. 
257. ВЕСТНИК ДРЕВНЕЙ ИСТОРИИ (2001) nr 236-237:

(Nr 236) Е.В. Герцман - Богослужебная музыка общины терапевтов 31-40; Е.Д. Матусова - Филон Александрийский и греческая доксографиа 40-52; A.В. Муравьев - Martyres sub Juliano Apostata, I: Действительное место мучения святых Мануила, Савела и Исмоила 53-60; А.И. Павловская - Афанасий, архиепископ Александрийский и его епархия 60-79; И.С. Свенцицкая - Новые подходы к возникновению Христианства (работы Дж.Д. Сроссана 88-97; (Nr 237) Д.Е. Афиногенов - Церковнославянский перевод Жития св. Порфирия Газского Марка Диакона и его текстологическое значение 46-51; А.В. Сергин - Ориген и стоическая концепция "вечного возвращения» (no De princ. II 3, 4 C. Cels. 4, 67-68; 5, 20-21), 52-70.

258. WIADOMOŚCI HISTORYCZNE (2000) nr 2-3:

T. Stępień - Dziedzictwo antyku we wczesnym chrześcijaństwie 65-77.

259. WIECZERNIK 12 (2001) nr 110:

T. Grysa - Sanguis martyrum semen christianorum 13-15.

260. ВОПРОСЫ ФИЛОСОФИИ (2001) nr 1-12:

(Nr 10) A.А. Белый - Ценностная компонента науки и становление оптики (он Августина до Леонардо да Винчи) 114-128.

261. WORT UND DIENST 26 (2001):

P. Prestel - Kain und Abel (Gen 4, 1-16) bei Flavius Josephus 73-88; A. Lindemann - Schwangerschaftsabbruch als ethisches Problem im antiken Judentum und im frühen Christentum 127-148.

262. ZEITSCHRIFT FÜR ÄGYPTISCHE SPRACHE UND ALTERTUMKUNDE 128 (2001) nr 1-2:

F. Feder - Der Wert einer lexikologischen Untersuchung der koptischen Bibelübersetzung für die ägyptische Lexikographie 7-23.

263. ZEITSCHRIFT FÜR ANTIKES CHRISTENTUM 5 (2001) nr 1-2:

H. Förster - Papyrusfragmente eines sahidischen ,Corpus Paulinum” 3-22;

W. Pradels - R. Brändle - M. Heimgartner-Das bisher vermisste Textstück in Johannes Chrysostomus, "Adversus Judaeos", Oratio 2, 23-49; G. Bonney - The Exegesis of the Gospel of Luke in the "Expositio evangelii secundum Lucam" of Ambrose and in the "In Lucae evangelium expositio» of Bede as observed in the Figure of Elisabeth 50-64; J. Zachhuber Basil and the Three-Hypostases Tradition. Reconsidering the origins of Cappadocian theology 65-85; K. Fitschen - Der "Praefectus Praetorio" Flavius Rufinus - ein hoher Reichsbeamter als Gestalt der Kirchengeschichte zur Zeit der „Theodosianischen Wende” 86-103; V.H. Drecoll - Neuplatonismus und Christentum bei Ambrosius, "De Isaac et anima»104-130; K. Nickau - Eine Historia Lausiaca ohne Lausos. Überlegungen zur Hypothese von Rene Draguet über den Ursprung der "Historia Lausiaca»131139; T.J. Kraus - P. Vindob. G 2325: Das sogenannte Fayûm-Evangelium - 
Neuedition und kritische Rückschlüsse 197-212; S. Gerber - Calixt von Rom und der monarchianische Streit 213- 239; R. Hennings - Eusebius von Emesa und die Juden 240-260; K.E. McVey - Ephrem The Syrian's Use of Female Metaphors to Describe the Deity 261-288; L. Abramowski - Die Mosaiken von S. Vitale und S. Apollinare in Classe und die Kirchenpolitik Kaiser Justinians 289-341.

264. ZEITSCHRIFT FÜR DIE NEUTESTAMENTLICHE WISSENSCHAFT 92 (2001) nr 1-4:

J. A. Kelhoffer - The Witness of Eusebius' ad Marinum and Other Christian Writings to Text-Critical Debates concerning the Original Conclusion to Mark's Gospel 78-112; J.M. Robinson - Ch. Heil - Noch einmal: Der Schreibfehler in Q 12, 27, 113-122; P. Lampe - Unchristliche Missionswege nach Rom: Haushalte paganer Herrschaft als jüdisch-christliche Keimzellen 123-127; P. Nagel - Das Gleichnis vom zerbrochenen Krug. EvThom Logion 97, 229-256; A.D. Baum - Ein aramäischer Urmatthäus im kleinasiatischen Gottesdienst. Das Papiaszeugnis zur Entstehung des Matthäusevangeliums 257-272.

265. ZEITSCHRIFT FÜR RELIGIONS- UND GEISTESGESCHICHTE 53 (2001) nr 1-4:

J. Dochhorn - Zur Entstehungsgeschichte der Religion bei Euhemeros - mit einem Ausblick auf Philo von Byblos 289-301.

266. ZESZYTY FILOZOFICZNE 9 (2001):

A. Jocz - Pomiędzy bytem a niebytem, czyli o istocie zła i jego wzajemnych relacjach $z$ dobrem $w$ nauczaniu Orygenesa 77-94.

267. ZESZYTY FORMACJI DUCHOWEJ (2001) nr 15-17:

(Nr 15) J. Figiel - Ojcowie Kościoła o cierpieniu 25-35.

268. ZESZYTY KARMELITAŃSKIE (2001) nr 1-4:

(Nr 1) J. Zieliński - Karmelici i ich Święta Góra. Zanim pojawili się karmelici 105-111.

269. ZESZYTY MARYJNE 4 (2001) nr 1-6:

(Nr 1) O. Bruno - Świadectwo Ojców. Jezus zrodzony z Boga iz Maryi (św. Hipolit) 14-15; ( Nr 2) O. Bruno - Świadectwo Ojców. Obrońca Matki Zbawiciela (św. Atanazy) 14-15; (Nr 3) O. Bruno - Świadectwo Ojców. Piewca Maryi, która zrodziła Zbawiciela (św. Efrem) 14-15; (Nr 4) O. Bruno - Świadectwo Ojców. Nauczyciel pobożności maryjnej (Epifaniusz z Salaminy) 14-15; (Nr 5) O. Bruno - Świadectwo Ojców. Katecheta z Jerozolimy (Cyryl Jerozolimski) 14-15; (Nr 6) O. Bruno - Świadectwo Ojców. Obrońca tytułu „Matka Boga” (Cyryl Aleksandryjski) 14-15.

270. ZIEMIA ŚWIĘTA 7 (2001) nr 1-4:

M. Piccivillo - Świeczniki wiary (mnisi syryjscy) 14-19; C.M. Paczkowski -

Nieznane skarby. Piśmiennictwo i literatura chrześcijańskiej Syrii 20-23.

271. ŻYCIE DUCHOWE (2001) nr 25-28: 
(Nr 27) H. Pietras - Agape i eros, czyli „ascetyzm semantyczny” 86-90. 272. ŻYCIE KONSEKROWANE (2001) nr 29-32:

(Nr 31) E.J. Jezierska - Kobiety konsekrowane w życiu Kościoła pierwotnego 31-39.

zebrał

Józef Figiel SDS - Lublin, KUL 